Article

\title{
Effect of Different Additives on Reaction Characteristics of Fluorapatite During Coal-Based Reduction of Iron Ore
}

\author{
Yongsheng Sun, Wentao Zhou *(D), Yuexin Han and Yanjun Li \\ School of Resources and Civil Engineering, Northeastern University, Shenyang 110819, China \\ * Correspondence: 13840541273@163.com; Tel.: +86-138-4054-1273
}

Received: 22 July 2019; Accepted: 21 August 2019; Published: 23 August 2019

check for updates

\begin{abstract}
In the coal-based reduction of high phosphorus oolitic hematite, it is particularly important to study the mechanism of phosphorus regulation during the formation of iron metals for the efficient development and utilization of iron ore. In this study, the thermodynamics of the coal-based reduction process of fluorapatite in different mineral systems, effect mechanism of the reduction degree, kinetics, mineral composition, and morphology of structural evolution samples were systematically investigated using FactSage software, single factor analysis, the isothermal method, X-ray diffraction (XRD), scanning electron microscope (SEM), and an energy dispersive spectrometer (EDS). Thermodynamic analysis indicates that the effect of the $\mathrm{SiO}_{2}-\mathrm{Fe}_{2} \mathrm{O}_{3}-\mathrm{C}$ system on reducing the initial reduction temperature of fluorapatite was stronger than that of the $\mathrm{Al}_{2} \mathrm{O}_{3}-\mathrm{Fe}_{2} \mathrm{O}_{3}-\mathrm{C}$ system. The effect mechanism of the reduction degree demonstrates that increasing the dosage of silica, iron oxide, carbon, reduction time, and reduction temperature could promote the reduction reaction of fluorapatite under certain conditions. Dynamics analysis shows that the best kinetic mechanism functions of the $\mathrm{SiO}_{2}-\mathrm{Fe}_{2} \mathrm{O}_{3}-\mathrm{C}$ system and the $\mathrm{Al}_{2} \mathrm{O}_{3}-\mathrm{Fe}_{2} \mathrm{O}_{3}-\mathrm{C}$ system were $\mathrm{A}_{1 / 3}=1 / 3(1-\alpha)[-\ln (1-$ $\alpha)]^{-2}$ and $\mathrm{A}_{1 / 2}=1 / 2(1-\alpha)[-\ln (1-\alpha)]^{-1}$, respectively. The activation energy and pre-exponential factor of the reduction kinetics equation in the system containing silica were significantly lower than that in the system containing alumina, which explained that the catalytic effect of silica on the reduction of calcium fluorophosphate was far greater than that of alumina. XRD and SEM/EDS analysis indicate that the solid-solid reaction of alumina, silica, iron, and fluorapatite occurred during the reduction process, while calcium aluminate, calcium silicate, and calcium oxide were formed at the contact point. Among them, iron could absorb $\mathrm{P}_{2}$ gas so that it played a greater role in promoting the reduction of fluorapatite. Increasing the reduction temperature and prolonging the reduction time were beneficial to the reduction of fluorapatite.
\end{abstract}

Keywords: fluorapatite; coal-based reduction; kinetic parameters; phase transformation; structure evolution

\section{Introduction}

In recent years, due to the rapid development of the iron and steel industry and the shortage of high-quality iron ore resources, the field of mineral processing and metallurgy has paid more attention to complex refractory iron ore [1,2]. As a typical complex refractory iron ore, high phosphorus oolitic hematite (phosphorus content is $0.4-1.8 \%$ ) accounts for about $7 \%$ of the total iron ore resources in China, with a total amount of 3.72 billion tons [3]. However, owing to its complex mineral composition, unique oolitic structure, fine grain size, and high content of harmful phosphorus, it is considered to be one of the most difficult iron ores to separate and utilize in the world [4-8]. Many scholars at home and abroad have carried out a large number research works on high-phosphorus oolitic hematite, 
which were mainly traditional mineral processing technologies, including magnetic separation and flotation, magnetization roasting technology, a leaching process, and a smelting process [9-17]. However, due to the complex mineralogical characteristics of high-phosphorus oolitic hematite, they have failed to meet the ideal separation index and environmental requirements.

Due to the traditional beneficiation methods not being effective enough for the treatment of high-phosphorus oolitic hematite, this study broke through the beneficiation-sintering-smelting process and firstly proposed coal-based reduction followed by magnetic separation technology for the treatment of high-phosphorus oolitic hematite and other complex refractory ores [18-20]. The complex refractory iron ore that cannot be directly used as blast furnace raw material is reduced to metallic iron at higher temperature and stronger reduction atmosphere than magnetized roasting. By controlling the reduction conditions, the metallic iron grows into an iron particle with a certain size, and the iron element tends to be $\mathrm{Fe}_{2} \mathrm{O}_{3} \rightarrow \mathrm{Fe}_{3} \mathrm{O}_{4} \rightarrow \mathrm{FeO} \rightarrow$ Fe during coal-based reduction. Products with stable composition, uniform particle size, high grade, high recovery, and a high metallization rate can be obtained after grinding and magnetic separation. Although the iron element can be efficiently enriched and recovered from high-phosphorus oolitic hematite by coal-based reduction followed by magnetic separation, the phosphorus minerals in the high-phosphorus oolitic hematite can be reduced to elemental phosphorus in the process. The reduced phosphorus element migrates to the metallic iron phase and binds with the elemental iron to form iron phosphide [3]. As a harmful element in the process of smelting, phosphorus is easy to cause cold brittleness in steel [21]. Therefore, many researchers have carried out a series of works on the reaction characteristics of phosphorus minerals and the regulation of phosphorus elements in the reduction process [22-24]. Two processes containing coal-based reduction for dephosphorization and coal-based reduction for phosphorus enrichment have been proposed. For the dephosphorization process, the effects of ore particle size, reduction temperature, alkalinity of the slag phase, dosage of reductant, and dephosphorization agent on the dephosphorization effect of high-phosphorus oolitic hematite were studied. The coal-based reduction-phosphorus enrichment process that promotes the enrichment of most phosphorus in the ferrous metal phase by controlling the coal-based reduction conditions for ores that have a high phosphorus content and are difficult to effectively dephosphorize. After the reduction products are efficiently separated, the reduced iron powder with phosphorus content of more than $1.5 \%$ can be obtained. Although the regulation of phosphorus (mainly in fluoroapatite) in the coal-based reduction of high-phosphorus oolitic hematite has gradually become the focus of scientific researchers, the current research work is still focused on the selection of dephosphorizing agents and the optimization of process parameters. The reduction reaction regulation of phosphorus minerals, as well as the factors and mechanisms affecting the reduction reaction of phosphorus minerals have not been carried out, which makes it difficult to make breakthroughs in the direction and control of phosphorus element.

In this study, the thermodynamic simulation software FactSage 6.4 was used to calculate the reduction reaction of phosphorus minerals in different systems, and the effect of the main components in high-phosphorus oolitic hematite on the reduction of phosphorus minerals was analyzed. Coal-based reduction experiments of phosphorus minerals were carried out. In order to lay a foundation for the regulation of the trend of phosphorus element, by analyzing and calculating the reduction degree of phosphorus minerals at different reduction times, the reduction kinetics model of phosphorus minerals in different systems was established. XRD and SEM were used to detect the coal-based reduction products of phosphorus minerals, and the interfacial reaction behavior and phase evolution between phosphorus minerals and reducing agents and additives under different reduction conditions were obtained. 


\section{Materials and Methods}

\subsection{Materials}

The apatite used in the experiment is produced from an apatite mine in Hubei Province, which is located in the central part of China. The grade of phosphorus is $18.23 \%$, and the theoretical grade of phosphorus in fluorapatite is $18.53 \%$. Therefore, the content of apatite can be calculated as high as $98.38 \%$. XRD phase analysis is shown in Figure 1. The results show the main mineral of apatite was fluorapatite. The reducing agent used in the test was coke. The analysis results are shown in Table 1 . Table 1 shows that the fixed carbon content of the reductant was $85.44 \%$, the ash and volatile content were $12.46 \%$ and $1.26 \%$, respectively, and the sulfur content was $0.62 \%$. The reagents used in this experiment are shown in Table 2.

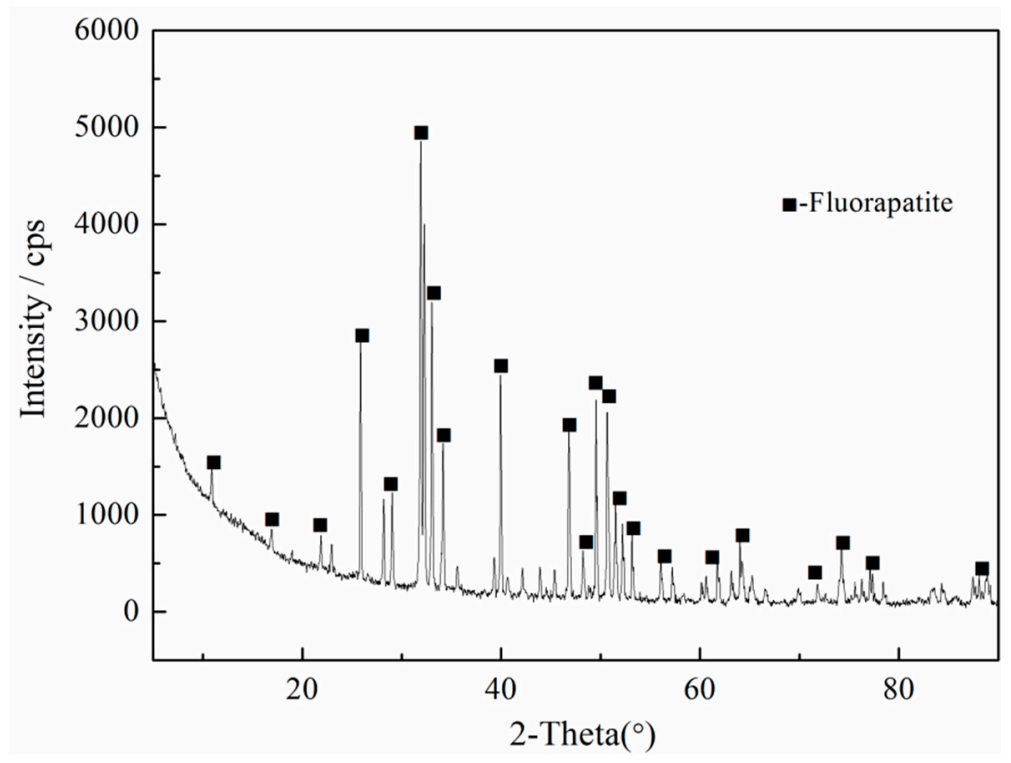

Figure 1. XRD pattern of phosphorite.

Table 1. Chemical compositions of coke (mass $\%)$.

\begin{tabular}{ccccc}
\hline Fixed Carbon & Volatile & Ash & Water & S \\
\hline 85.44 & 1.26 & 12.46 & 0.22 & 0.62 \\
\hline
\end{tabular}

Table 2. Reagents used in experiments.

\begin{tabular}{ccc}
\hline Reagent Name & Chemical Formula & Specifications \\
\hline Silicon dioxide & $\mathrm{SiO}_{2}$ & Analytical Purity \\
Alumina & $\mathrm{Al}_{2} \mathrm{O}_{3}$ & Analytical Purity \\
Ferric oxide & $\mathrm{Fe}_{2} \mathrm{O}_{3}$ & Analytical Purity \\
\hline
\end{tabular}

\subsection{Methods and Equipment}

FactSage 6.4 was used to simulate the reduction process of phosphorus minerals in various systems. The main component of apatite chosen in this study is fluoroapatite; therefore, $\mathrm{Ca}_{10}\left(\mathrm{PO}_{4}\right)_{6} \mathrm{~F}_{2}$ was used as the chemical formula of phosphorus minerals in thermodynamic analysis. $\mathrm{Fe}_{2} \mathrm{O}_{3}, \mathrm{SiO}_{2}$, $\mathrm{CaO}$, and $\mathrm{Al}_{2} \mathrm{O}_{3}$ are the main components of high-phosphorus oolitic hematite; in order to explore their effects on the reduction of phosphorus minerals, they are used as additives [1,3]. Meanwhile, the thermodynamic analysis of $\mathrm{Ca}_{10}\left(\mathrm{PO}_{4}\right)_{6} \mathrm{~F}_{2}-\mathrm{Al}_{2} \mathrm{O}_{3}-\mathrm{Fe}_{2} \mathrm{O}_{3}-\mathrm{C}$ and $\mathrm{Ca}_{10}\left(\mathrm{PO}_{4}\right)_{6} \mathrm{~F}_{2}-\mathrm{SiO}_{2}-\mathrm{Fe}_{2} \mathrm{O}_{3}-\mathrm{C}$ were carried out using carbon as a reducing agent. The mass ratio of the two additives to $\mathrm{Ca}_{10}\left(\mathrm{PO}_{4}\right)_{6} \mathrm{~F}_{2}$ was 1:1:10. The C/O molar ratio of each system is 2.0 . 
Coal-based reduction experiments of various systems of phosphate minerals were carried out in a laboratory muffle furnace. A certain amount of phosphorus minerals, additives, and coke were mixed evenly according to the test conditions. The carbon distribution coefficient in this study is expressed by the $\mathrm{C} / \mathrm{O}$ molar ratio. When the $\mathrm{C} / \mathrm{O}$ molar ratio is 1 , the amount of carbon required is the fixed carbon required to completely reduce fluoroapatite and iron mineral to phosphorus and iron, while carbon is oxidized to CO. The uniformly mixed material was put into a graphite crucible, and a layer of coke powder was covered on the surface of the crucible to keep the reducing atmosphere in the crucible. The crucible with material was put into the furnace after the temperature reaches the specified value. This process takes a very short time, and has little effect on the temperature change; the target temperature can be reached in a few minutes after the crucible with material was put into furnace. When the temperature in the furnace rises to the target temperature, the timing begins. The crucible is taken out for water quenching treatment when the reduction proceeds to a specified time. After water quenching, the reduction material is grinded to the particle size of $85 \mathrm{wt} . \%$ minus $74 \mu \mathrm{m}$. The grinded material is put into the oven to dry, and 15-g representative products are taken out. The fined material begins magnetic separation by a XCSG-50 magnetic separator under the condition of $107 \mathrm{kA} / \mathrm{m}$ magnetic field intensity. The phosphorus in magnetic separation concentrate belongs to a reduced phosphorus, while the phosphorus in the magnetic separation tailings (a gangue phase) belongs to unreduced phosphorus; the phosphorus content is determined after weighing the magnetic separation tailings, and the reduction degree of apatite can be calculated by Equation (1):

$$
\alpha=\left(1-\frac{m \times \gamma_{S} \times w_{P}}{m_{P}}\right) \times 100
$$

where $\alpha$ is the fluoroapatite reduction degree, wt. $\% ; m$ is the mass of the reduced product, $g ; \gamma_{S}$ is the mass ratio of magnetic separation tailings to magnetic separation feeds; $w_{\mathrm{P}}$ is the phosphorus content in magnetic separation tailings, wt.\%; and $m_{\mathrm{P}}$ is the phosphorus mass in phosphorus minerals at each test, $\mathrm{g}$.

In order to explore the reaction mechanism and the expression of the reaction rate of phosphorus minerals under different conditions, we determined the limiting link of the reaction process and obtained the influence of various factors on the reduction rate. In order to select suitable reduction conditions and realize the regulation of the reduction of phosphorus minerals, the kinetics experiments of $\mathrm{Ca}_{10}\left(\mathrm{PO}_{4}\right)_{6} \mathrm{~F}_{2}-\mathrm{Al}_{2} \mathrm{O}_{3}-\mathrm{Fe}_{2} \mathrm{O}_{3}-\mathrm{C}$ and $\mathrm{Ca}_{10}\left(\mathrm{PO}_{4}\right)_{6} \mathrm{~F}_{2}-\mathrm{SiO}_{2}-\mathrm{Fe}_{2} \mathrm{O}_{3}-\mathrm{C}$ systems were carried out by the isothermal method. Under isothermal conditions, the kinetic equations of homogeneous or heterogeneous chemical reactions are shown in Equation (2). The integral form of Equation (2) is shown in Equation (3):

$$
r=\frac{d \alpha}{d t}=k(T) f(\alpha)
$$

where $T$ is the reduction time, $\min ; k(T)$ is the reaction rate constant, $\min ^{-1}$; and $f(a)$ is the reaction mechanism function.

$$
G(\alpha)=\int_{0}^{\alpha} \frac{d \alpha}{f(\alpha)}=\int_{0}^{t} k(T) d t=k(T) t
$$

The kinetic models of chemical reaction mainly include the Avrami-Erofeev equation, diffusion model, power function rule, shrinkage core model, and chemical reaction model [23,24]. Sixteen commonly used kinetic mechanism function models were selected to study the linear relationship between $G(\alpha)$ and the reduction time. The $f(\alpha)$ corresponding to $G(\alpha)$ with the highest linear correlation was the best mechanism function for the reduction of fluorapatite in this system, and the slope of the regression line was the reaction rate constant $k(T)$. Table 3 shows the differential and integral forms of 16 commonly used kinetic mechanism functions. For a given chemical reaction, the reaction rate constant $k(T)$ is temperature-dependent, and can be expressed by the Arrhenius equation, as shown in Equations (4) and (5).

$$
k(T)=A \exp \left(\frac{-E_{a}}{R T}\right)
$$




$$
\ln k(T)=-\frac{E_{a}}{R T}+\ln A
$$

where $A$ is the pre-exponential factor, $\min ^{-1} ; T$ is the reduction temperature, $\mathrm{K} ; E_{a}$ is the apparent activation energy of the reaction, $\mathrm{J} \cdot \mathrm{mol}^{-1}$; and $\mathrm{R}$ is the gas constant, $\mathrm{R}=8.314 \mathrm{~J} \cdot \mathrm{mol}^{-1} \cdot \mathrm{K}^{-1}$.

Table 3. Differential and integral expressions of common reaction mechanism functions.

\begin{tabular}{|c|c|c|c|}
\hline Code & Reaction Model & Differential $f(\alpha)$ & Integral $G(\alpha)$ \\
\hline $\mathrm{A}_{m}$ & Avrami-Erofeev & $m(1-\alpha)[-\ln (1-\alpha)]^{(m-1) / m}$ & {$[-\ln (1-\alpha)]^{1 / m}$} \\
\hline $\mathrm{A}_{1}$ & $m=1$ & $1-\alpha$ & $-\ln (1-\alpha)$ \\
\hline $\mathrm{A}_{2}$ & $m=2$ & $2(1-\alpha)[-\ln (1-\alpha)]^{1 / 2}$ & {$[-\ln (1-\alpha)]^{1 / 2}$} \\
\hline $\mathrm{A}_{3}$ & $m=3$ & $3(1-\alpha)[-\ln (1-\alpha)]^{2 / 3}$ & {$[-\ln (1-\alpha)]^{1 / 3}$} \\
\hline $\mathrm{A}_{4}$ & $m=4$ & $4(1-\alpha)[-\ln (1-\alpha)]^{3 / 4}$ & {$[-\ln (1-\alpha)]^{1 / 4}$} \\
\hline $\mathrm{A}_{3 / 2}$ & $m=3 / 2$ & $3 / 2(1-\alpha)[-\ln (1-\alpha)]^{1 / 3}$ & {$[-\ln (1-\alpha)]^{2 / 3}$} \\
\hline $\mathrm{A}_{1 / 4}$ & $m=1 / 4$ & $1 / 4(1-\alpha)[-\ln (1-\alpha)]^{-3}$ & {$[-\ln (1-\alpha)]^{4}$} \\
\hline $\mathrm{A}_{1 / 3}$ & $m=1 / 3$ & $1 / 3(1-\alpha)[-\ln (1-\alpha)]^{-2}$ & {$[-\ln (1-\alpha)]^{3}$} \\
\hline $\mathrm{A}_{1 / 2}$ & $m=1 / 2$ & $1 / 2(1-\alpha)[-\ln (1-\alpha)]^{-1}$ & {$[-\ln (1-\alpha)]^{2}$} \\
\hline $\mathrm{D}_{m}$ & Diffusion & & \\
\hline $\mathrm{D}_{1}$ & One-dimensional diffusion & $1 / 2 \alpha^{-1}$ & $\alpha^{2}$ \\
\hline $\mathrm{D}_{2}$ & 2-D diffusion (Valensi) & {$[-\ln (1-\alpha)]^{-1}$} & $\alpha+(1-\alpha) \ln (1-\alpha)$ \\
\hline $\mathrm{D}_{3}$ & 2-D diffusion (Jander) & $(1-\alpha)^{1 / 2}\left[1-(1-\alpha)^{1 / 2}\right]^{-1}$ & {$\left[1-(1-\alpha)^{1 / 2}\right]^{2}$} \\
\hline $\mathrm{D}_{4}$ & 3-D diffusion (anti-Jander) & $3 / 2(1+\alpha)^{2 / 3}\left[(1+\alpha)^{1 / 3}-1\right]^{-1}$ & {$\left[(1+\alpha)^{1 / 3}-1\right]^{2}$} \\
\hline$D_{5}$ & 3-D diffusion (Z-L-T) & $3 / 2(1-\alpha)^{4 / 3}\left[(1-\alpha)^{-1 / 3}-1\right]^{-1}$ & {$\left[(1-\alpha)^{-1 / 3}-1\right]^{2}$} \\
\hline $\mathrm{D}_{6}$ & 3-D diffusion (Jander, $\mathrm{n}=2$ ) & $3 / 2(1-\alpha)^{2 / 3}\left[1-(1-\alpha)^{1 / 3}\right]^{-1}$ & {$\left[1-(1-\alpha)^{1 / 3}\right]^{2}$} \\
\hline $\mathrm{D}_{7}$ & 3-D diffusion (Jander, $n=1 / 2$ ) & $6(1-\alpha)^{2 / 3}\left[1-(1-\alpha)^{1 / 3}\right]^{1 / 2}$ & {$\left[1-(1-\alpha)^{1 / 3}\right]^{1 / 2}$} \\
\hline $\mathrm{D}_{8}$ & 3-D diffusion (G-B) & $\left.3 / 2[(1-\alpha)]^{-1 / 3}-1\right]^{-1}$ & $1-2 / 3 \alpha-(1-\alpha)^{2 / 3}$ \\
\hline
\end{tabular}

A Hitachi F-7000 fluorescence spectrophotometer was used to detect the content of phosphorus in the reduction products. Detailed phase information of the reduction products was detected by $\mathrm{X}$-ray diffraction (XRD) with $\mathrm{Cu} \mathrm{K} \alpha$ radiation, where the operating voltage and current were $40 \mathrm{kV}$ and $40 \mathrm{~mA}$, respectively. The diffraction angle was scanned from $5^{\circ}$ to $90^{\circ}$ with the scanning rate of $12^{\circ} / \mathrm{min}$. Hitachi S-3400N scanning electron microscopy (SEM, Hitachi Technology Co., Ltd. from Tokyo, Japan) was used to characterize the microstructures of the products obtained under different reduction conditions. The working parameters have an acceleration voltage of $20 \mathrm{kV}$. An energy dispersive spectrometer (EDS) was used for surface scanning element analysis.

\section{Results and Discussion}

\subsection{Thermodynamic Analysis}

The Equilib module in FactSage 6.4 was used to calculate the equilibrium phase composition of the two systems in the range of $1000{ }^{\circ} \mathrm{C}$ to $1600{ }^{\circ} \mathrm{C}$. The thermodynamic calculation of the possible chemical reactions in the two systems was carried out using a reaction module, as shown in Figure 2.

As can be seen from Figure 2, in the $\mathrm{Ca}_{10}\left(\mathrm{PO}_{4}\right)_{6} \mathrm{~F}_{2}-\mathrm{Al}_{2} \mathrm{O}_{3}-\mathrm{Fe}_{2} \mathrm{O}_{3}-\mathrm{C}$ system, a small amount of calcium fluorophosphate had been reduced, and $\mathrm{CaAl}_{12} \mathrm{O}_{19}$ and $\mathrm{Fe}_{3} \mathrm{P}$ had been formed when the calculating temperature was lower than $1175^{\circ} \mathrm{C}$, which was necessary for the defluorination reaction of fluoroapatite. The chemical equation of the reduction reaction is shown in Equation (6). With the increase of calculating temperature, the reaction products of fluorapatite with alumina and iron were mainly $\mathrm{CaAl}_{2} \mathrm{O}_{4}$ and $\mathrm{Fe}_{\mathrm{x}} \mathrm{P}$. When the calculating temperature was higher than $1400{ }^{\circ} \mathrm{C}$, a large number of liquid slag was formed in the system. The liquid slag was mainly composed of $\mathrm{Al}_{2} \mathrm{O}_{3}$ and $\mathrm{CaO}$. By calculating the relationship between Gibbs free energy and temperature in the range of $1000{ }^{\circ} \mathrm{C}$ to $1600{ }^{\circ} \mathrm{C}$, the initial temperature of Equation (6) was $1059^{\circ} \mathrm{C}$.

$$
\mathrm{Ca}_{10}\left(\mathrm{PO}_{4}\right)_{6} \mathrm{~F}_{2}+54 \mathrm{Al}_{2} \mathrm{O}_{3}+15 \mathrm{C}+18 \mathrm{Fe}=\mathrm{CaF}_{2}+9 \mathrm{CaAl}_{12} \mathrm{O}_{19}+6 \mathrm{Fe}_{3} \mathrm{P}+15 \mathrm{CO}
$$



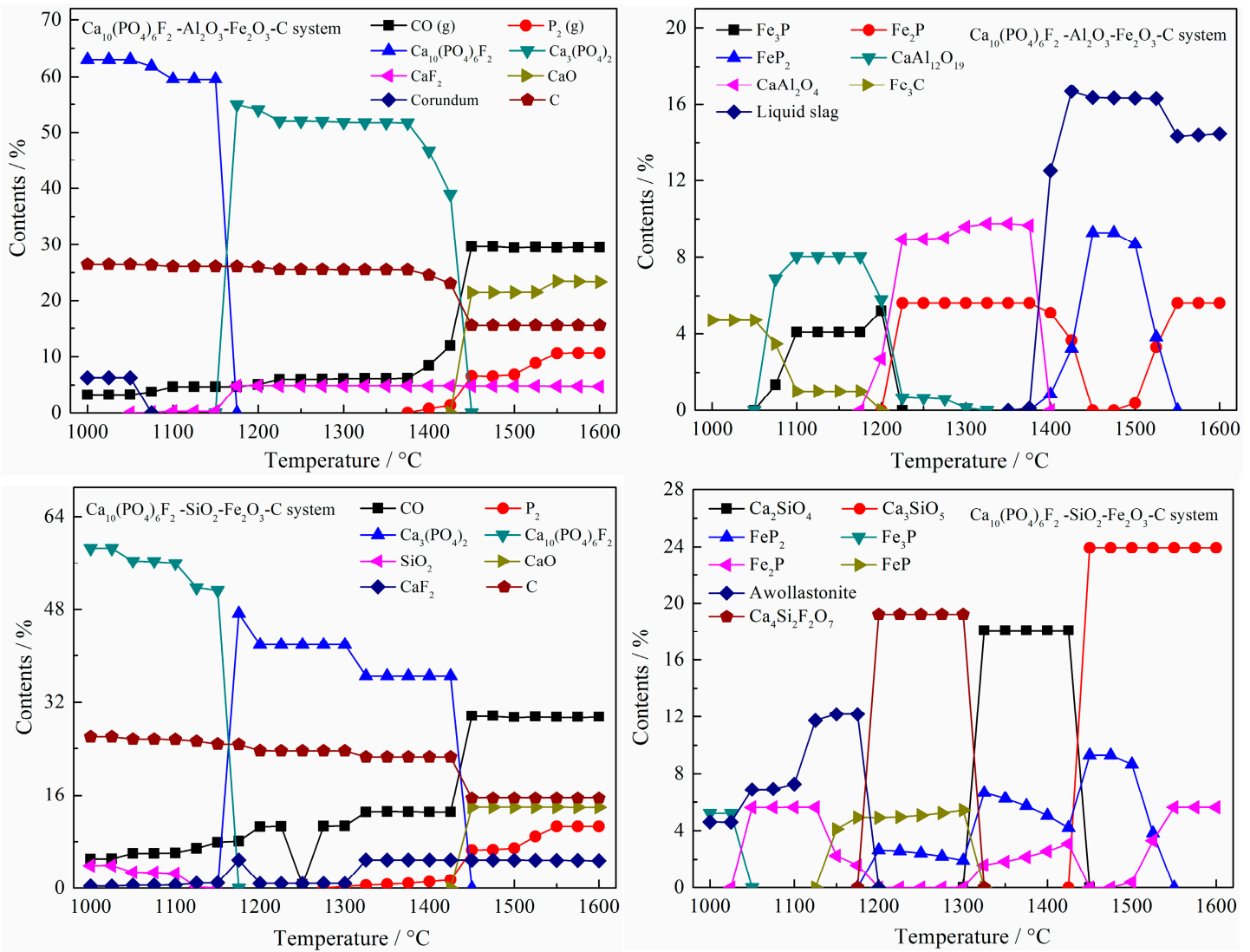

Figure 2. Relationship between equilibrium composition (wt.\%) and temperature of the system of $\mathrm{Ca}_{10}\left(\mathrm{PO}_{4}\right)_{6} \mathrm{~F}_{2}-\mathrm{Al}_{2} \mathrm{O}_{3}-\mathrm{Fe}_{2} \mathrm{O}_{3}-\mathrm{C}$ and $\mathrm{Ca}_{10}\left(\mathrm{PO}_{4}\right)_{6} \mathrm{~F}_{2}-\mathrm{SiO}_{2}-\mathrm{Fe}_{2} \mathrm{O}_{3}-\mathrm{C}$.

In the $\mathrm{Ca}_{10}\left(\mathrm{PO}_{4}\right)_{6} \mathrm{~F}_{2}-\mathrm{SiO}_{2}-\mathrm{Fe}_{2} \mathrm{O}_{3}-\mathrm{C}$ system, when the calculating temperature was $1000{ }^{\circ} \mathrm{C}$, with the promotion of silicon dioxide and iron, when the reaction reaches equilibrium, fluorapatite had been reduced to wollastonite $\left(\mathrm{CaSiO}_{3}\right)$ and $\mathrm{Fe}_{3} \mathrm{P}$ products in this system. The chemical equation of the reduction reaction is shown in Equation (7). With the increase of calculating temperature, the order of formation of different forms of calcium silicate was: $\mathrm{CaSiO}_{3}, \mathrm{Ca}_{4} \mathrm{Si}_{2} \mathrm{~F}_{2} \mathrm{O}_{7}\left(\mathrm{Ca}_{2} \mathrm{Si}_{2} \mathrm{O}_{7}\right), \mathrm{Ca}_{2} \mathrm{SiO}_{4}, \mathrm{Ca}_{3} \mathrm{SiO}_{5}$. The Gibbs free energy of reaction 7 in the range of $900{ }^{\circ} \mathrm{C}$ to $1600{ }^{\circ} \mathrm{C}$ was calculated. The initial temperature of Equation (7) was $985^{\circ} \mathrm{C}$.

$$
\mathrm{Ca}_{10}\left(\mathrm{PO}_{4}\right)_{6} \mathrm{~F}_{2}+9 \mathrm{SiO}_{2}+15 \mathrm{C}+18 \mathrm{Fe}=\mathrm{CaF}_{2}+9 \mathrm{CaSiO}_{3}+6 \mathrm{Fe}_{3} \mathrm{P}+15 \mathrm{CO}
$$

\subsection{Reduction Degree Analysis}

The factors affecting the reduction of fluorapatite were studied. The effects of reduction time, temperature, carbon content, and additives on the reduction of fluorapatite were investigated. The results are shown in Figures 3-6. 


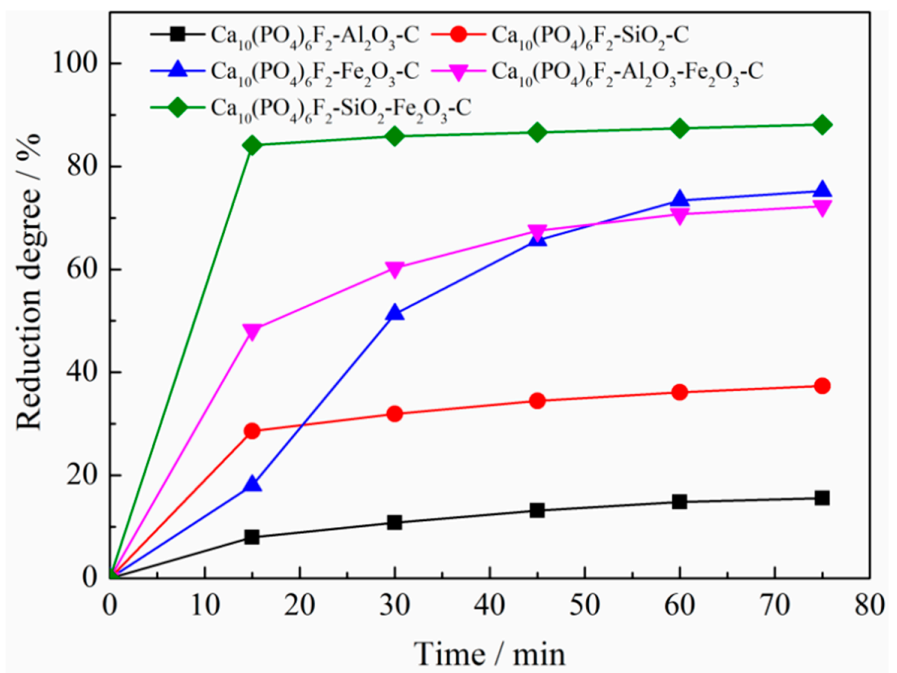

Figure 3. Effect of reduction time on the reduction degree of fluorapatite.

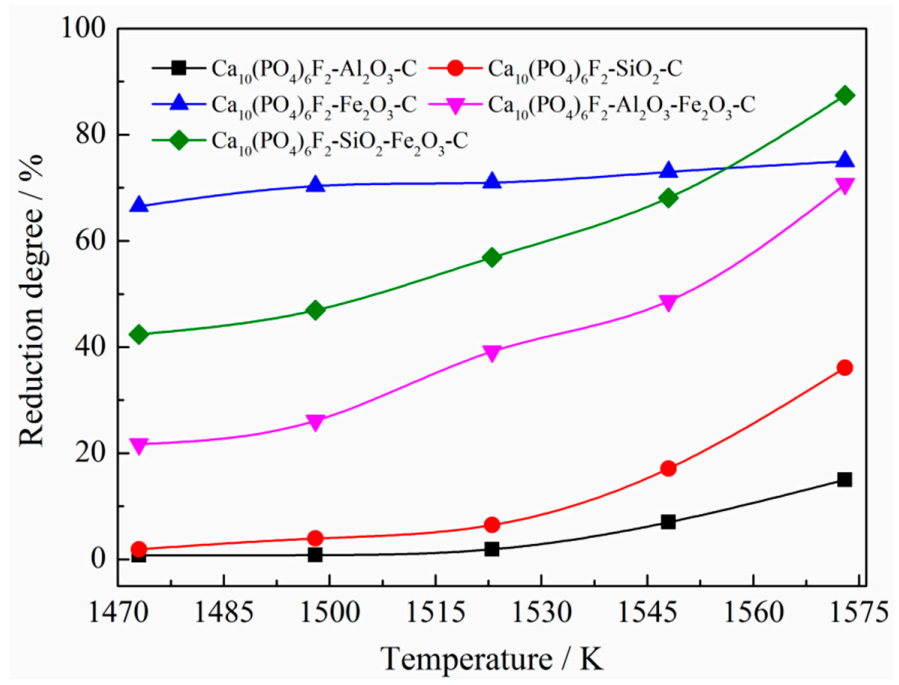

Figure 4. Effect of reduction temperature on the reduction degree of fluorapatite.

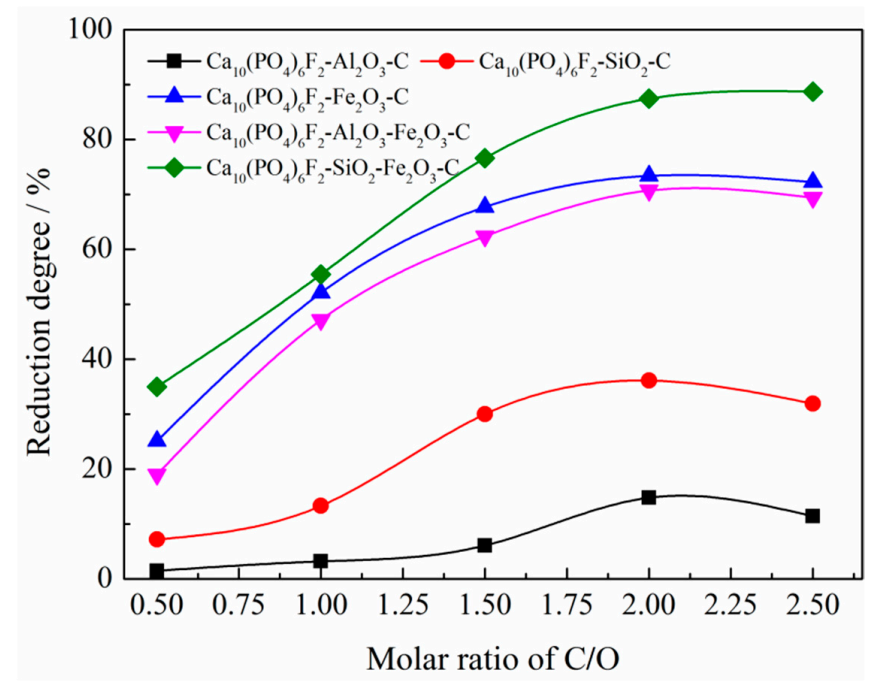

Figure 5. Effect of $\mathrm{C} / \mathrm{O}$ molar ratio on the reduction degree of fluorapatite. 


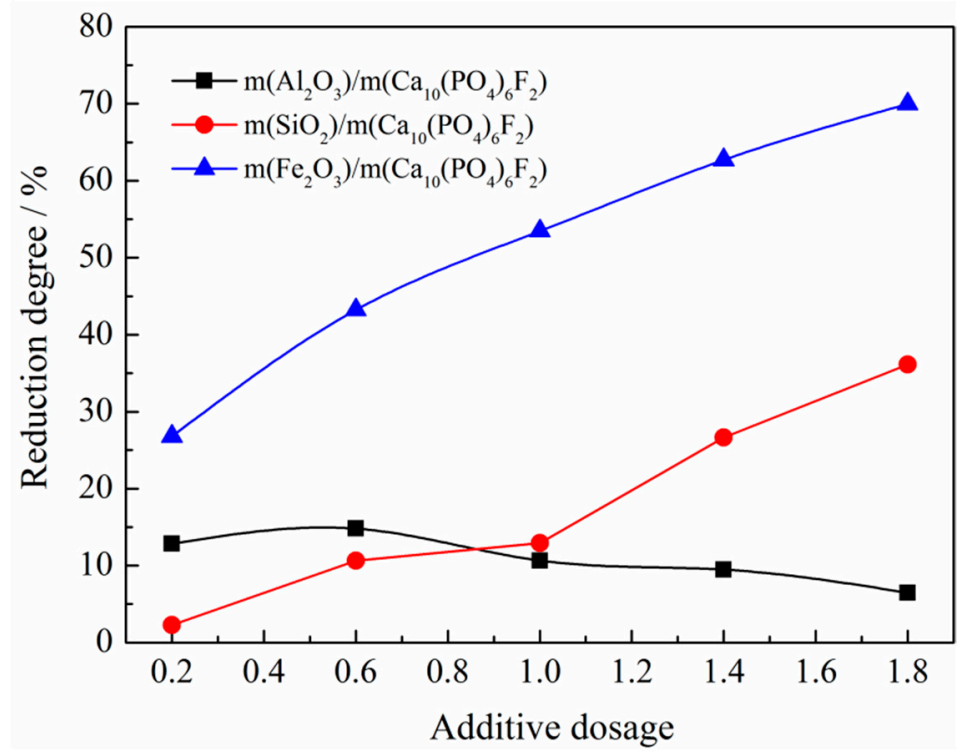

Figure 6. Effect of additive contents on the reduction degree of fluorapatite.

\subsubsection{Effects of Reduction Time}

Figure 3 indicates that the reduction degree of fluorapatite increased with the increase of reduction time when the additive was $\mathrm{SiO}_{2}$ or $\mathrm{Al}_{2} \mathrm{O}_{3}$. However, the content of reductant decreased gradually with the increase of reduction time; in addition, the phase interface reaction of fluorapatite was hindered by the newly formed reductive products, which resulted in the decrease of the growth rate of reduction degree. When the additive was $\mathrm{Fe}_{2} \mathrm{O}_{3}$, in the initial stage of the reaction, the reduction rate of metal iron increased slightly because of the small amount of iron, which promoted the reduction of fluorapatite; the growth rate of the reduction degree of fluorapatite increased first and then decreased with the increase of reduction time.

\subsubsection{Effects of Reduction Temperature}

Figure 4 shows that increasing the reduction temperature was conducive to the occurrence of various reduction reactions, thereby increasing the reduction degree. When the additive was $\mathrm{Fe}_{2} \mathrm{O}_{3}-\mathrm{SiO}_{2}$ or $\mathrm{Fe}_{2} \mathrm{O}_{3}-\mathrm{Al}_{2} \mathrm{O}_{3}$, fluorapatite was mainly reduced by carbon under the promotion of silica (alumina) at a lower reduction temperature, while iron oxide played a more prominent role at a higher temperature.

\subsubsection{Effects of Carbon Content}

Figure 5 exhibits that the molar ratio of $\mathrm{C} / \mathrm{O}$ that was the most conducive to the reduction of fluorapatite was 2.0. Increasing the molar ratio of $\mathrm{C} / \mathrm{O}$ would increase the contact area between fluorapatite and the reductant, which was conducive to the reduction of fluorapatite. When the reductant was excessive, coke would reduce the fusibility of materials and hinder the reaction between the additives and fluorapatite, which was not conducive to the reduction of fluorapatite.

\subsubsection{Effects of Additive Contents}

Figure 6 illustrates that the reduction degree of fluorapatite increased with the increase of the dosage of additives $\mathrm{Al}_{2} \mathrm{O}_{3}, \mathrm{SiO}_{2}$, and $\mathrm{Fe}_{2} \mathrm{O}_{3}$, at the following the reduction conditions: a molar ratio of $\mathrm{C} / \mathrm{O} 2.0$, reduction time of $1 \mathrm{~h}$, and reduction temperature of $1300{ }^{\circ} \mathrm{C}$. When the content ratio of $\mathrm{Al}_{2} \mathrm{O}_{3}$, $\mathrm{SiO}_{2}$, and $\mathrm{Fe}_{2} \mathrm{O}_{3}$ to fluorapatite reached 0.6, 1.8 and 1.8 in turn, the continuous increase of additives would hinder the contact between fluorapatite and the reductant. At this time, the growth rate of the reduction degree gradually approached zero or even became negative. When the mass ratios of $\mathrm{Al}_{2} \mathrm{O}_{3}$, 
$\mathrm{SiO}_{2}$, and $\mathrm{Fe}_{2} \mathrm{O}_{3}$ to fluorapatite are less than $0.6,1.8$, and 1.8, respectively, the reduction degree of fluorapatite increases in order of abundance with the following additives: $\mathrm{Fe}_{2} \mathrm{O}_{3}, \mathrm{SiO}_{2}$, and $\mathrm{Al}_{2} \mathrm{O}_{3}$.

\subsection{Kinetic Analysis}

The ratios of $\mathrm{Al}_{2} \mathrm{O}_{3}, \mathrm{SiO}_{2}$, and $\mathrm{Fe}_{2} \mathrm{O}_{3}$ to fluoroapatite in $\mathrm{Ca}_{10}\left(\mathrm{PO}_{4}\right)_{6} \mathrm{~F}_{2}-\mathrm{Al}_{2} \mathrm{O}_{3}-\mathrm{Fe}_{2} \mathrm{O}_{3}-\mathrm{C}$ and $\mathrm{Ca}_{10}\left(\mathrm{PO}_{4}\right)_{6} \mathrm{~F}_{2}-\mathrm{SiO}_{2}-\mathrm{Fe}_{2} \mathrm{O}_{3}-\mathrm{C}$ systems were adjusted to $0.6,1.8$, and 1.8 , respectively. The coal-based reduction experiments were carried out under the conditions of a $\mathrm{C} / \mathrm{O}$ molar ratio of 2.0, reduction temperatures of $1473 \mathrm{~K}, 1498 \mathrm{~K}, 1523 \mathrm{~K}$, and $1573 \mathrm{~K}$, and reduction times of $15 \mathrm{~min}, 30 \mathrm{~min}, 45 \mathrm{~min}$, $60 \mathrm{~min}$, and $75 \mathrm{~min}$, respectively. The content of phosphorus in the reduction products was tested, and the relationship between the reduction degree and reduction time of fluorapatite under different conditions in the two systems were obtained as shown in Figure 7.
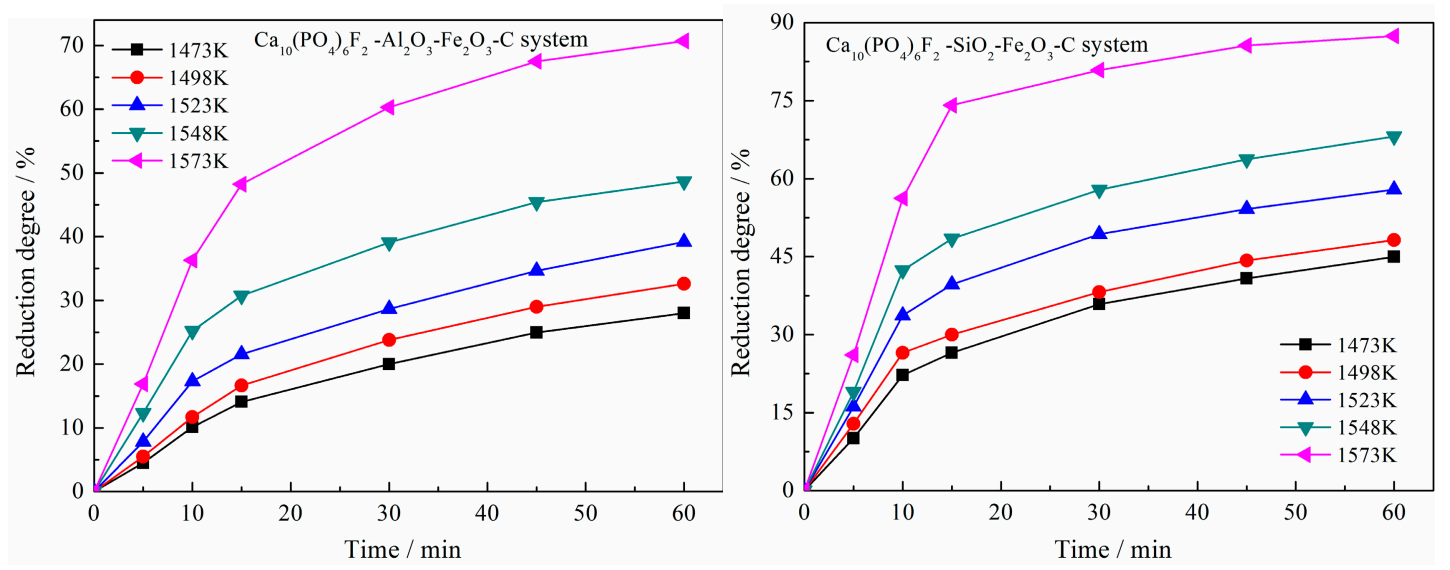

Figure 7. Effect of reduction time on the reduction degree of fluorapatite in systems of $\mathrm{Ca}_{10}\left(\mathrm{PO}_{4}\right)_{6} \mathrm{~F}_{2}-\mathrm{Al}_{2} \mathrm{O}_{3}-\mathrm{Fe}_{2} \mathrm{O}_{3}-\mathrm{C}$ and $\mathrm{Ca}_{10}\left(\mathrm{PO}_{4}\right)_{6} \mathrm{~F}_{2}-\mathrm{SiO}_{2}-\mathrm{Fe}_{2} \mathrm{O}_{3}-\mathrm{C}$.

The reduction degree and reduction time of fluorapatite were introduced into Equation (3) at different reduction temperatures for the $\mathrm{Ca}_{10}\left(\mathrm{PO}_{4}\right)_{6} \mathrm{~F}_{2}-\mathrm{Al}_{2} \mathrm{O}_{3}-\mathrm{Fe}_{2} \mathrm{O}_{3}-\mathrm{C}$ and $\mathrm{Ca}_{10}\left(\mathrm{PO}_{4}\right)_{6} \mathrm{~F}_{2}-\mathrm{SiO}_{2}-\mathrm{Fe}_{2} \mathrm{O}_{3}-\mathrm{C}$ systems. Linear fitting between $G(\alpha)$ and the reduction time was performed under 16 kinetic mechanism function models as shown in Table 3, and the linear correlation coefficients were calculated as shown in Table 4. From the correlation coefficients in Table 4, it can be seen that the optimal kinetic mechanism functions of the reduction reaction of fluorapatite in $\mathrm{Ca}_{10}\left(\mathrm{PO}_{4}\right)_{6} \mathrm{~F}_{2}-\mathrm{Al}_{2} \mathrm{O}_{3}-\mathrm{Fe}_{2} \mathrm{O}_{3}-\mathrm{C}$ and $\mathrm{Ca}_{10}\left(\mathrm{PO}_{4}\right)_{6} \mathrm{~F}_{2}-\mathrm{SiO}_{2}-\mathrm{Fe}_{2} \mathrm{O}_{3}-\mathrm{C}$ systems were $\mathrm{A}_{1 / 2}: 1 / 2(1-\alpha)[-\ln (1-$ $\alpha)]^{-1}$ and $\mathrm{A}_{1 / 3}: 1 / 3(1-\alpha)[-\ln (1-\alpha)]^{-2}$, respectively. The slope of each regression line corresponding to the mechanism function was the apparent reaction rate. The reaction rate $k(T)$ at each temperature was substituted into Equation (3), and the linear fitting of $\ln k(T)$ and $1 / T$ was carried out. The fitting curve was shown in Figure 8. The activation energy and pre-exponential factor of the selected reduction mechanism function of fluorapatite in $\mathrm{Ca}_{10}\left(\mathrm{PO}_{4}\right)_{6} \mathrm{~F}_{2}-\mathrm{Al}_{2} \mathrm{O}_{3}-\mathrm{Fe}_{2} \mathrm{O}_{3}-\mathrm{C}$ and $\mathrm{Ca}_{10}\left(\mathrm{PO}_{4}\right)_{6} \mathrm{~F}_{2}-\mathrm{SiO}_{2}-\mathrm{Fe}_{2} \mathrm{O}_{3}-\mathrm{C}$ systems were obtained by calculating the slope and intercept of the regression line, as shown in Table 5 . 
Table 4. Correlation coefficients calculated using common reaction mechanism functions.

\begin{tabular}{|c|c|c|c|c|c|c|c|c|c|c|}
\hline \multirow{4}{*}{$\begin{array}{l}\text { Function } \\
\text { Code }\end{array}$} & \multicolumn{10}{|c|}{ Experimental Conditions/K } \\
\hline & \multicolumn{5}{|c|}{$\mathrm{Ca}_{10}\left(\mathrm{PO}_{4}\right)_{6} \mathrm{~F}_{2}-\mathrm{Al}_{2} \mathrm{O}_{3}-\mathrm{Fe}_{2} \mathrm{O}_{3}-\mathrm{C}$} & \multicolumn{5}{|c|}{$\mathrm{Ca}_{10}\left(\mathrm{PO}_{4}\right)_{6} \mathrm{~F}_{2}-\mathrm{SiO}_{2}-\mathrm{Fe}_{2} \mathrm{O}_{3}-\mathrm{C}$} \\
\hline & 1473 & 1498 & 1523 & 1548 & 1573 & 1473 & 1498 & 1523 & 1548 & 1573 \\
\hline & \multicolumn{10}{|c|}{ Correlation Coefficients $R^{2}, \times 10^{-4}$} \\
\hline $\mathbf{A}_{m}$ & \multicolumn{10}{|c|}{ Avrami-Erofeev Equation, $f(x)=m(1-x)[-\ln (1-x)]^{(m-1) / m}$} \\
\hline $\mathrm{A}_{1}$ & 9433 & 9436 & 9367 & 8944 & 8863 & 9030 & 8993 & 8529 & 8508 & 7879 \\
\hline $\mathrm{A}_{2}$ & 8590 & 8627 & 8474 & 8029 & 7885 & 8084 & 8071 & 7522 & 7368 & 6765 \\
\hline $\mathrm{A}_{3}$ & 8208 & 8263 & 8080 & 7656 & 7479 & 7691 & 7695 & 7130 & 6926 & 6342 \\
\hline $\mathrm{A}_{4}$ & 7998 & 8064 & 7867 & 7458 & 7263 & 7482 & 7497 & 6927 & 6698 & 6124 \\
\hline $\mathrm{A}_{3 / 2}$ & 8923 & 8944 & 8821 & 8370 & 8253 & 8440 & 8415 & 7888 & 7782 & 7165 \\
\hline $\mathrm{A}_{1 / 4}$ & 9331 & 9334 & 9208 & 9754 & 9789 & 9659 & 9646 & 9904 & 9754 & 9910 \\
\hline $\mathrm{A}_{1 / 3}$ & 9777 & 9795 & 9731 & 9962 & 9950 & 9953 & 9937 & 9993 & 9976 & 9805 \\
\hline $\mathrm{A}_{1 / 2}$ & 9984 & 9991 & 9977 & 9848 & 9802 & 9906 & 9884 & 9681 & 9750 & 9263 \\
\hline $\mathbf{D}_{m}$ & \multicolumn{10}{|c|}{ Diffusion } \\
\hline $\mathrm{D}_{1}$ & 9943 & 9927 & 9891 & 9482 & 8954 & 9623 & 9545 & 8971 & 8708 & 6820 \\
\hline $\mathrm{D}_{2}$ & 9963 & 9957 & 9936 & 9626 & 9294 & 9736 & 9683 & 9241 & 9125 & 7657 \\
\hline$D_{3}$ & 9971 & 9969 & 9953 & 9695 & 9466 & 9789 & 9747 & 9376 & 9334 & 8186 \\
\hline $\mathrm{D}_{4}$ & 9902 & 9870 & 9808 & 9290 & 8635 & 9461 & 9355 & 8670 & 8304 & 6363 \\
\hline$D_{5}$ & 9986 & 9995 & 9972 & 9916 & 9924 & 9957 & 9940 & 9827 & 9904 & 9705 \\
\hline$D_{6}$ & 9977 & 9979 & 9966 & 9753 & 9598 & 9834 & 9800 & 9489 & 9497 & 8591 \\
\hline $\mathrm{D}_{7}$ & 8508 & 8531 & 8340 & 7840 & 7528 & 7913 & 7881 & 7256 & 6982 & 6112 \\
\hline $\mathrm{D}_{8}$ & 9968 & 9966 & 9948 & 9673 & 9409 & 9772 & 9727 & 9331 & 9265 & 8004 \\
\hline
\end{tabular}

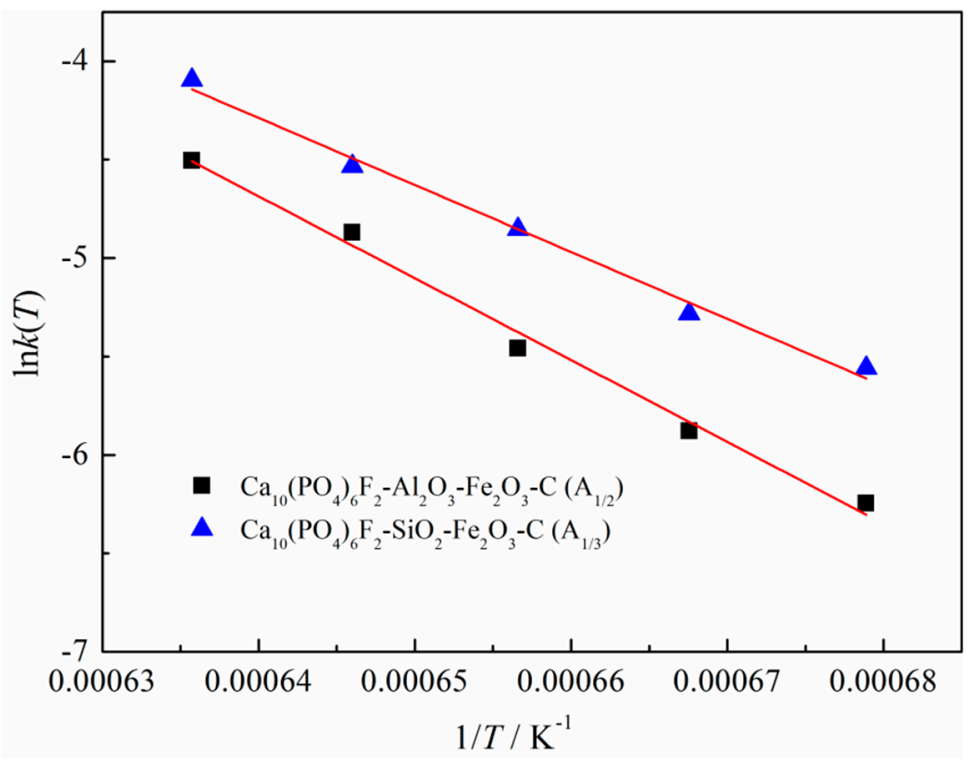

Figure 8. Linear fitting of $\ln k(T)$ versus $1 / T$.

Table 5. Kinetics parameters of apatite reduction.

\begin{tabular}{ccc}
\hline Mechanism Function & $\boldsymbol{k}(T)$ & $\mathbf{R}^{\mathbf{2}}$ \\
\hline $\mathrm{A}_{1 / 2}$ & $k(T)=\left(3.26789 \times 10^{9}\right) \exp \left(\frac{-345.478 \times 10^{3}}{R T}\right)$ & 0.9892 \\
\hline$\left(\mathrm{Ca}_{10}\left(\mathrm{PO}_{4}\right)_{6} \mathrm{~F}_{2}-\mathrm{Al}_{2} \mathrm{O}_{3}-\mathrm{Fe}_{2} \mathrm{O}_{3}-\mathrm{C}\right)$ & $k(T)=\left(3.89033 \times 10^{7}\right) \exp \left(\frac{-282.748 \times 10^{3}}{R T}\right)$ & 0.9904 \\
\hline $\mathrm{A}_{1 / 3}$ & \\
\hline$\left(\mathrm{Ca}_{10}\left(\mathrm{PO}_{4}\right)_{6} \mathrm{~F}_{2}-\mathrm{SiO}_{2}-\mathrm{Fe}_{2} \mathrm{O}_{3}-\mathrm{C}\right)$ &
\end{tabular}

Comparing the two systems, the activation energy and pre-exponential factor of the reduction kinetics equation of calcium fluorophosphate in the system containing silica were significantly lower than those in the system containing alumina. The chemical reactions tended to proceed along the pathway of lower activation energy. The activation energy could be considered as the energy needed to overcome in the reaction process, which indicated that calcium fluorophosphate was easier to 
reduce in the system containing silica than in the system containing alumina, and this conclusion was consistent with the thermodynamic analysis results. According to the transition state theory, the chemical reaction was carried out in two steps. First, the reactant molecules collided to form an active complex; then, they decomposed into products. Therefore, the higher the number of effective collisions between molecules, the easier the chemical reactions would occur. The pre-exponential factor, which is also known as the frequency factor, depended on whether the collision between molecules was effective. The higher the number of effective collisions, the lower the frequency of collisions required, and the lower the pre-exponential factor. The pre-exponential factor in the reduction kinetics equation of calcium fluorophosphate in the system containing silica was much lower than that in the system containing alumina, which further indicated that silica could promote the reduction of calcium fluorophosphate more than alumina.

\subsection{Phase Transformation}

In order to explore the phase change law of the coal-based reduction process in $\mathrm{Ca}_{10}\left(\mathrm{PO}_{4}\right)_{6} \mathrm{~F}_{2}-\mathrm{Al}_{2} \mathrm{O}_{3}-\mathrm{Fe}_{2} \mathrm{O}_{3}-\mathrm{C}$, an $\mathrm{X}$-ray diffraction analyzer (XRD) was used to analyze the phase change at reduction temperatures of $1473 \mathrm{~K}, 1523 \mathrm{~K}$, and $1573 \mathrm{~K}$ respectively, with a reduction time of $60 \mathrm{~min}$, a molar ratio of $\mathrm{C} / \mathrm{O}$ of 2.0, a dosage ratio of additives $\mathrm{Al}_{2} \mathrm{O}_{3}$ and $\mathrm{Fe}_{2} \mathrm{O}_{3}$ to $\mathrm{Ca}_{10}\left(\mathrm{PO}_{4}\right)_{6} \mathrm{~F}_{2}$ of 0.6 and 2.2. The results are shown in Figure 9.

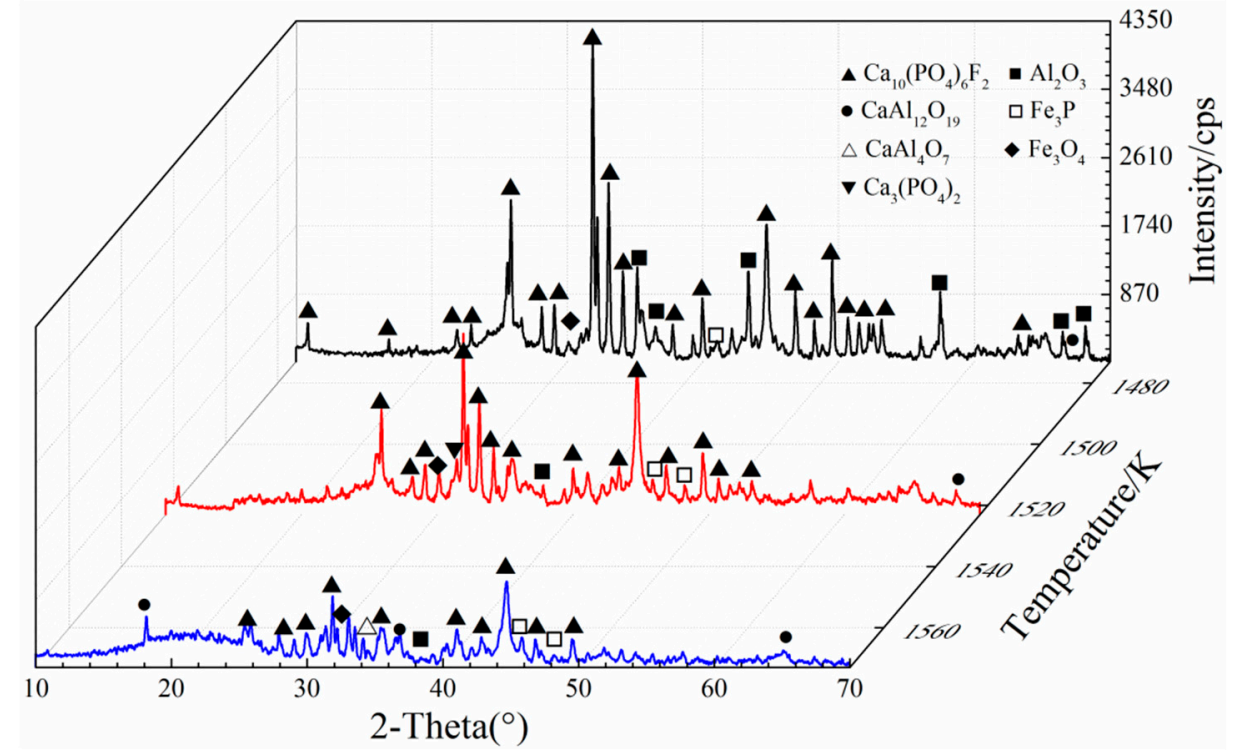

Figure 9. $\mathrm{XRD}$ pattern of the product of reduction at different temperature in the $\mathrm{Ca}_{10}\left(\mathrm{PO}_{4}\right)_{6} \mathrm{~F}_{2}-\mathrm{Al}_{2} \mathrm{O}_{3}-\mathrm{Fe}_{2} \mathrm{O}_{3}-\mathrm{C}$ system.

Figure 9 shows that the $\mathrm{XRD}$ spectra of the reduced products appeared at diffraction peaks for $\mathrm{Ca}_{10}\left(\mathrm{PO}_{4}\right)_{6} \mathrm{~F}_{2}, \mathrm{Al}_{2} \mathrm{O}_{3}, \mathrm{Fe}_{3} \mathrm{O}_{4}, \mathrm{CaAl}_{12} \mathrm{O}_{19}$, and $\mathrm{Fe}_{3} \mathrm{P}$ when the reduction temperature was $1473 \mathrm{~K}$. At this time, the intensity of the diffraction peaks of $\mathrm{Fe}_{3} \mathrm{P}$ and $\mathrm{CaAl}_{12} \mathrm{O}_{19}$ was relatively weak, which indicated that the reduction reaction of fluorapatite occurred mainly under the co-promotion of elemental iron and alumina at lower reduction temperatures. When the reduction temperature was $1523 \mathrm{~K}$, a new diffraction peak of $\mathrm{Ca}_{3}\left(\mathrm{PO}_{4}\right)_{2}$ appeared in the XRD diagram, the relative intensity of the diffraction peaks of $\mathrm{Fe}_{3} \mathrm{P}$ and $\mathrm{CaAl}_{12} \mathrm{O}_{19}$ increased, and the number of the diffraction peaks of $\mathrm{Fe}_{3} \mathrm{P}$ increased, while the relative intensity of the diffraction peaks of $\mathrm{Ca}_{10}\left(\mathrm{PO}_{4}\right)_{6} \mathrm{~F}_{2}$ and $\mathrm{Al}_{2} \mathrm{O}_{3}$ decreased significantly. This phenomenon shows that with the increase of the reduction temperature, the effect of metal iron on the reduction of apatite increased. When the reduction temperature was $1573 \mathrm{~K}$, the diffraction peaks of $\mathrm{CaAl}_{4} \mathrm{O}_{7}$ appeared; at present, the number of diffraction peaks of $\mathrm{CaAl}_{12} \mathrm{O}_{19}$ increased and the relative intensity increased. The relative intensity of the diffraction peaks of $\mathrm{Fe}_{3} \mathrm{P}$ and $\mathrm{Ca}_{3}\left(\mathrm{PO}_{4}\right)_{2}$ 
increased, while the relative intensity of the diffraction peaks of $\mathrm{Ca}_{10}\left(\mathrm{PO}_{4}\right)_{6} \mathrm{~F}_{2}$ and $\mathrm{Al}_{2} \mathrm{O}_{3}$ continued to decrease. The reaction process of the above reaction could be greatly promoted, and $\mathrm{CaAl}_{4} \mathrm{O}_{7}$ could be produced by the interaction of fluorapatite and alumina.

At different reduction temperatures, the coal-based reduction products of the $\mathrm{Ca}_{10}\left(\mathrm{PO}_{4}\right)_{6} \mathrm{~F}_{2}-\mathrm{SiO}_{2}-\mathrm{Fe}_{2} \mathrm{O}_{3}-\mathrm{C}$ system were analyzed by XRD under a reduction time of $60 \mathrm{~min}$, $\mathrm{C} / \mathrm{O}$ molar ratio of 2.0, and $\mathrm{SiO}_{2}$ and $\mathrm{Fe}_{2} \mathrm{O}_{3}$ to $\mathrm{Ca}_{10}\left(\mathrm{PO}_{4}\right)_{6} \mathrm{~F}_{2}$ content ratios of 1.8 and 1.8, respectively. The results are shown in Figure 10.

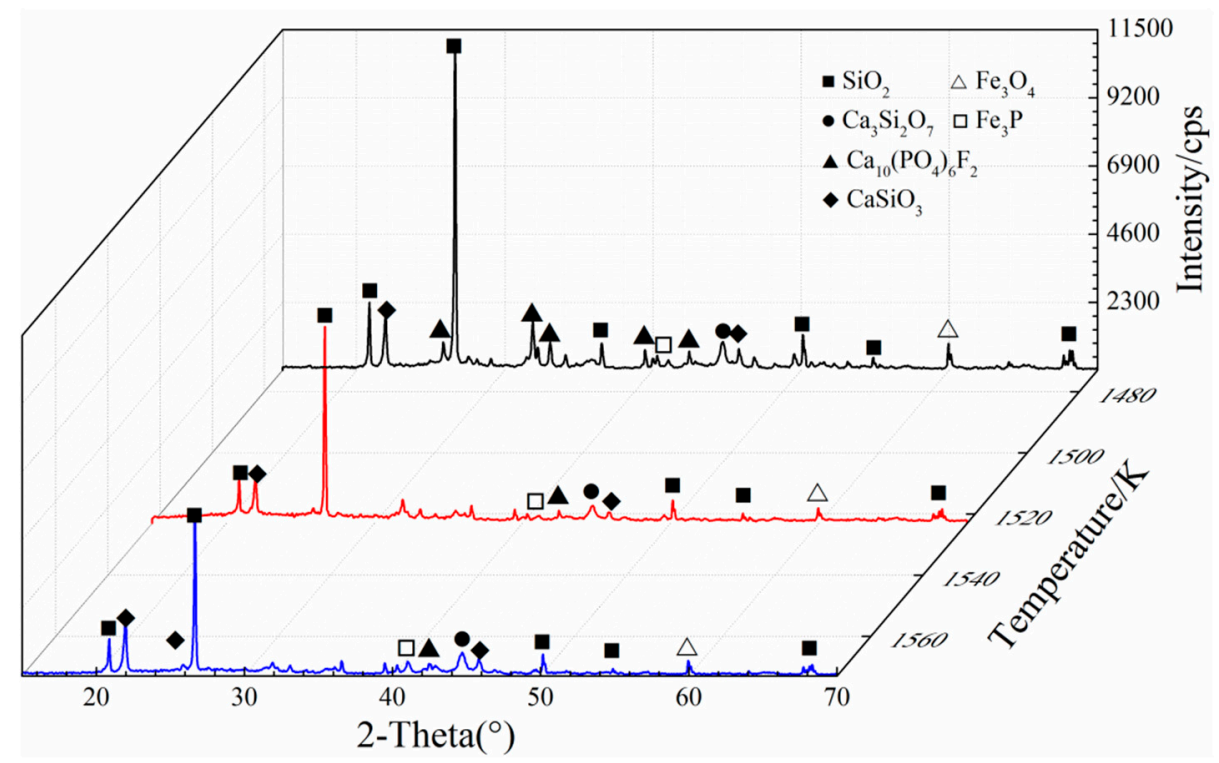

Figure 10. $\mathrm{XRD}$ pattern of the product of reduction at different temperatures in the $\mathrm{Ca}_{10}\left(\mathrm{PO}_{4}\right)_{6} \mathrm{~F}_{2}-\mathrm{SiO}_{2}-\mathrm{Fe}_{2} \mathrm{O}_{3}-\mathrm{C}$ system.

Figure 10 shows that when the reduction temperature was $1473 \mathrm{~K}$, the diffraction peaks of $\mathrm{Ca}_{10}\left(\mathrm{PO}_{4}\right)_{6} \mathrm{~F}_{2}, \mathrm{SiO}_{2}, \mathrm{Fe}_{3} \mathrm{O}_{4}, \mathrm{Fe}_{3} \mathrm{P}, \mathrm{Ca}_{3} \mathrm{Si}_{2} \mathrm{O}_{7}$, and $\mathrm{CaSiO}_{3}$ appeared. With the increase of reduction temperature, no new peaks appeared, but the relative intensity of the peaks of $\mathrm{Fe}_{3} \mathrm{P}_{2} \mathrm{Ca}_{3} \mathrm{Si}_{2} \mathrm{O}_{7}$, and $\mathrm{CaSiO}_{3}$ increased, while the relative intensity of the diffraction peaks of $\mathrm{Ca}_{10}\left(\mathrm{PO}_{4}\right)_{6} \mathrm{~F}_{2}$ and $\mathrm{SiO}_{2}$ decreased significantly. The results show that when the reduction temperature was $1473 \mathrm{~K}$, calcium fluorophosphate was reduced by carbon with the promotion of silicon dioxide and iron to form $\mathrm{Fe}_{3} \mathrm{P}, \mathrm{Ca}_{3} \mathrm{Si}_{2} \mathrm{O}_{7}$, and $\mathrm{CaSiO}_{3}$ products. The increase of temperature promoted the reaction process, but no new reaction occurred, which indicated that the initial temperature of each reaction was lower under the promotion of both silicon dioxide and iron.

\subsection{Morphology Structure Characterization}

The reduction products of the $\mathrm{Ca}_{10}\left(\mathrm{PO}_{4}\right)_{6} \mathrm{~F}_{2}-\mathrm{Al}_{2} \mathrm{O}_{3}-\mathrm{Fe}_{2} \mathrm{O}_{3}-\mathrm{C}$ system were analyzed by elemental scanning electron microscopy (SEM/EDS) under the conditions of a reduction temperature of $1473 \mathrm{~K}$ and reduction time of $60 \mathrm{~min}$. The results are shown in Figure 11.

It can be seen from Figure 11 that the main elements in the gray-white area in point 1 were $\mathrm{Ca}, \mathrm{P}$, $\mathrm{O}$, and a small amount of $\mathrm{F}$, which was composed of fluorapatite that has not been reduced. The bright white area in point 2 mainly contained Fe and a small amount of $P$, which indicated that only a small amount of fluorapatite was reduced in the area where point 1 is located. The area in point 3 mainly contained $\mathrm{Al}, \mathrm{O}$, and $\mathrm{Ca}$ elements, which was composed of calcium aluminate and unreacted alumina. The above analysis shows that when the reduction temperature was $1473 \mathrm{~K}$, fluorapatite reacted mainly with alumina and carbon, and the phosphorus content in the ferrous phase was less, and the promotion effect of ferrous metal on the reduction of fluorapatite was weaker. 

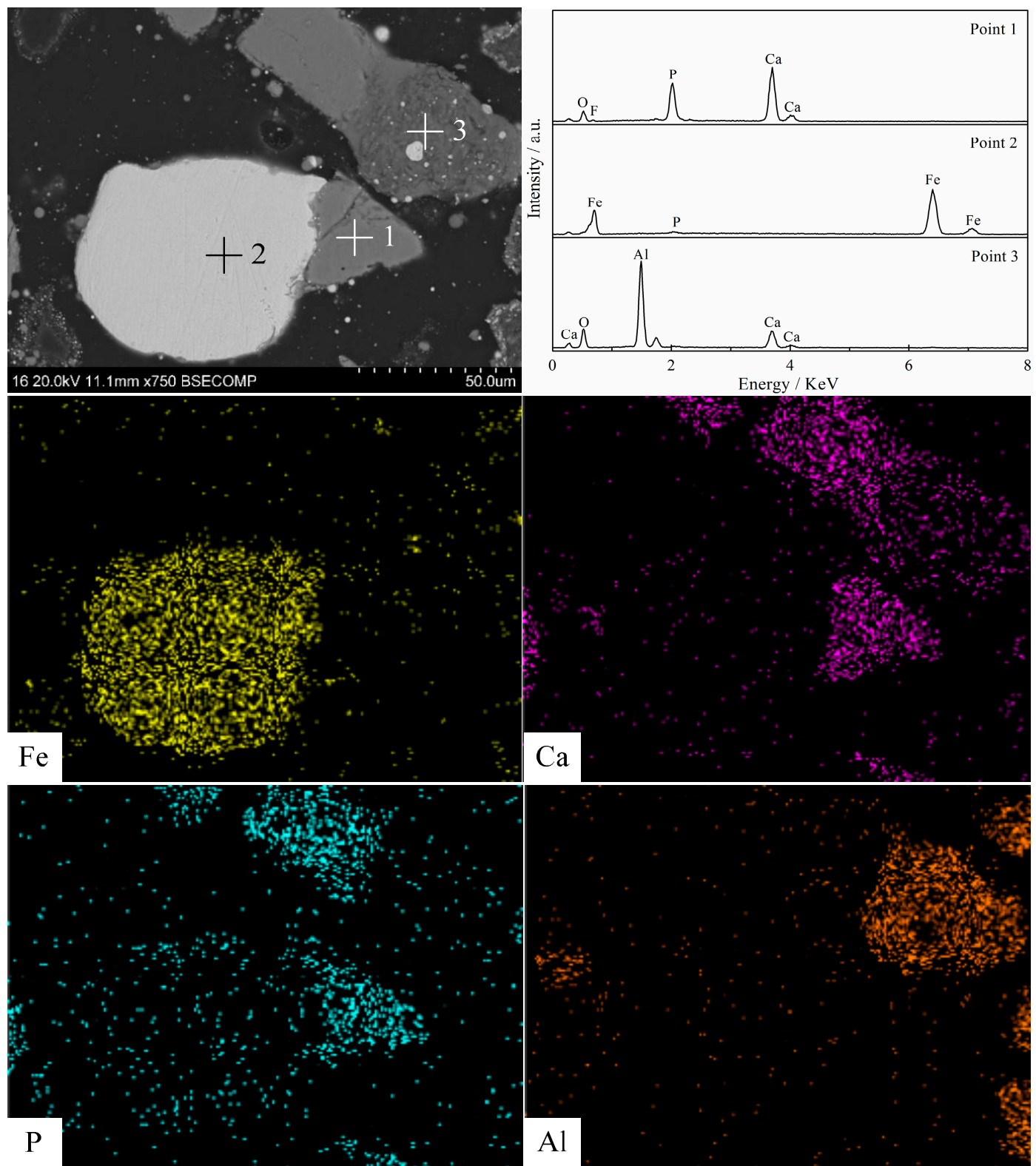

Figure 11. SEM image and energy dispersive spectrometer (EDS) spectra and line-by-line scanning analysis of the reduction product in the $\mathrm{Ca}_{10}\left(\mathrm{PO}_{4}\right)_{6} \mathrm{~F}_{2}-\mathrm{Al}_{2} \mathrm{O}_{3}-\mathrm{Fe}_{2} \mathrm{O}_{3}-\mathrm{C}$ system (reduction temperature of $1473 \mathrm{~K}$ and reduction time of $60 \mathrm{~min}$ ).

The reduction products of the $\mathrm{Ca}_{10}\left(\mathrm{PO}_{4}\right)_{6} \mathrm{~F}_{2}-\mathrm{Al}_{2} \mathrm{O}_{3}-\mathrm{Fe}_{2} \mathrm{O}_{3}-\mathrm{C}$ system were analyzed by elemental scanning electron microscopy (SEM/EDS) under the conditions of a reduction temperature of $1573 \mathrm{~K}$ and a reduction time of $10 \mathrm{~min}$. The results are shown in Figure 12. 




Figure 12. SEM image and EDS spectra and line-by-line scanning analysis of the reduction product in the $\mathrm{Ca}_{10}\left(\mathrm{PO}_{4}\right)_{6} \mathrm{~F}_{2}-\mathrm{Al}_{2} \mathrm{O}_{3}-\mathrm{Fe}_{2} \mathrm{O}_{3}-\mathrm{C}$ system (reduction temperature of $1573 \mathrm{~K}$ and reduction time of 10 $\min )$.

Figure 12 indicates that the gray-black area in point 6 was mainly composed of alumina, while the area in point 4 was a metal iron particle, which contained a certain amount of phosphorus, indicating that the metal iron played a certain role in promoting the reduction of fluorapatite. It can be seen from the surface scan that the gray-white area in point 5 contained many fine iron particles on the surface of alumina. The EDS energy spectrum shows that the area was mainly composed of calcium aluminate, which was the reaction product of fluorapatite and alumina. The above analysis shows that fluorapatite could be reduced by carbon under the co-promotion of alumina and iron at $1573 \mathrm{~K}$.

The reduction products of the $\mathrm{Ca}_{10}\left(\mathrm{PO}_{4}\right)_{6} \mathrm{~F}_{2}-\mathrm{Al}_{2} \mathrm{O}_{3}-\mathrm{Fe}_{2} \mathrm{O}_{3}-\mathrm{C}$ system were analyzed by elemental scanning electron microscopy (SEM/EDS) under the conditions of a reduction temperature of $1573 \mathrm{~K}$ and reduction time of $60 \mathrm{~min}$. The results are shown in Figure 13. 

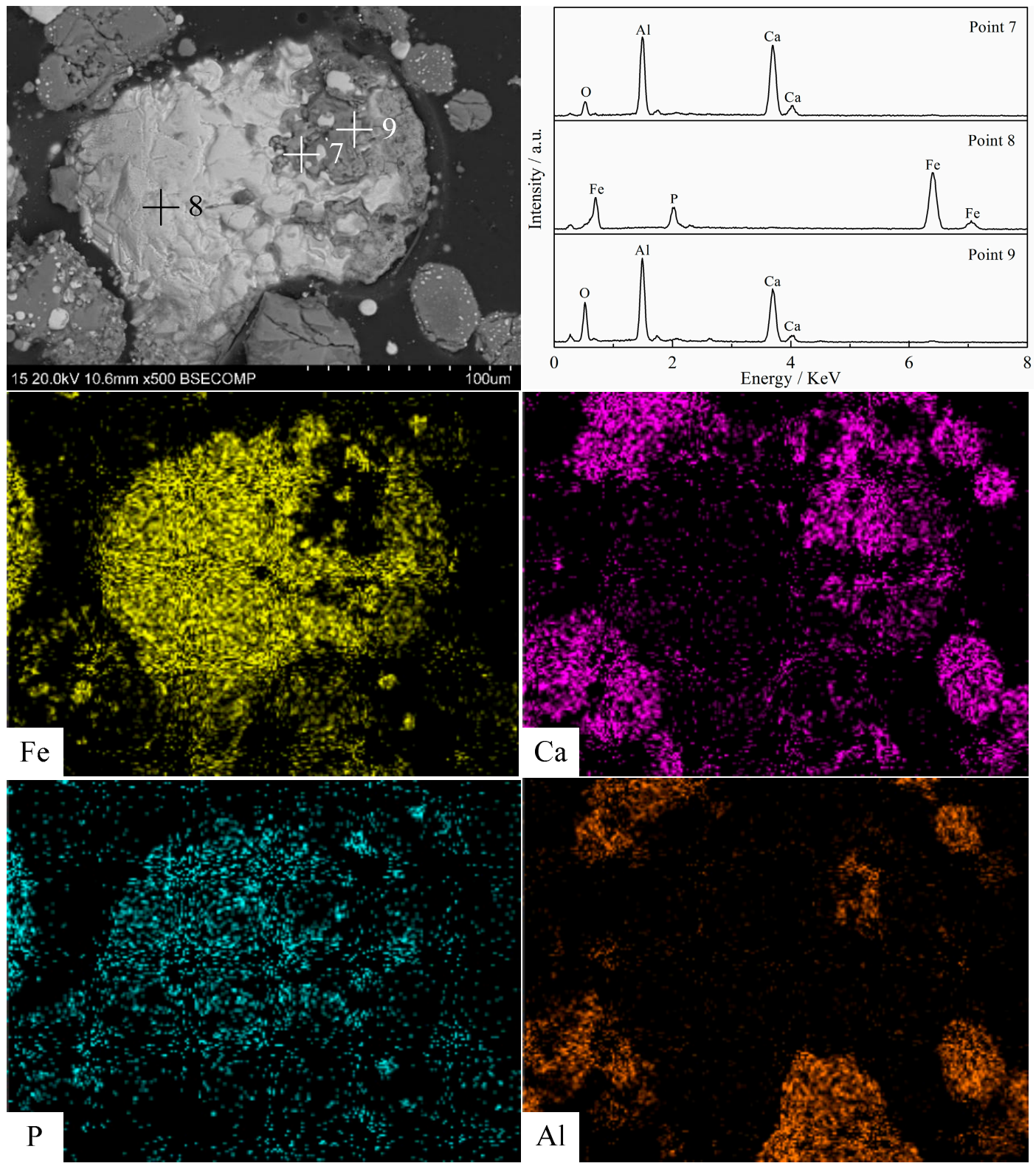

Figure 13. SEM image and EDS spectra and line-by-line scanning analysis of the reduction product in the $\mathrm{Ca}_{10}\left(\mathrm{PO}_{4}\right)_{6} \mathrm{~F}_{2}-\mathrm{Al}_{2} \mathrm{O}_{3}-\mathrm{Fe}_{2} \mathrm{O}_{3}-\mathrm{C}$ system (reduction temperature of $1573 \mathrm{~K}$ and reduction time of $60 \mathrm{~min}$ ).

Figure 13 states clearly that the content of $\mathrm{P}$ was very low outside the ferrous metal area in point 8 , while the content of $\mathrm{P}$ in the ferrous metal area was relatively high, which indicated that the fluorapatite in the area in point 8 had been reduced completely. Comparing the EDS spectra in points 7 and 9, it can be seen that the relative content of $\mathrm{Ca}$ was higher near the metal iron phase. Combining with thermodynamic analysis, it can be seen that the metal iron promoted the formation of calcium aluminate.

The reduction products of the $\mathrm{Ca}_{10}\left(\mathrm{PO}_{4}\right)_{6} \mathrm{~F}_{2}-\mathrm{SiO}_{2}-\mathrm{Fe}_{2} \mathrm{O}_{3}-\mathrm{C}$ system were analyzed by elemental scanning electron microscopy (SEM/EDS) under the conditions of a reduction temperature of $1473 \mathrm{~K}$ and reduction time of $60 \mathrm{~min}$. The results are shown in Figure 14. 

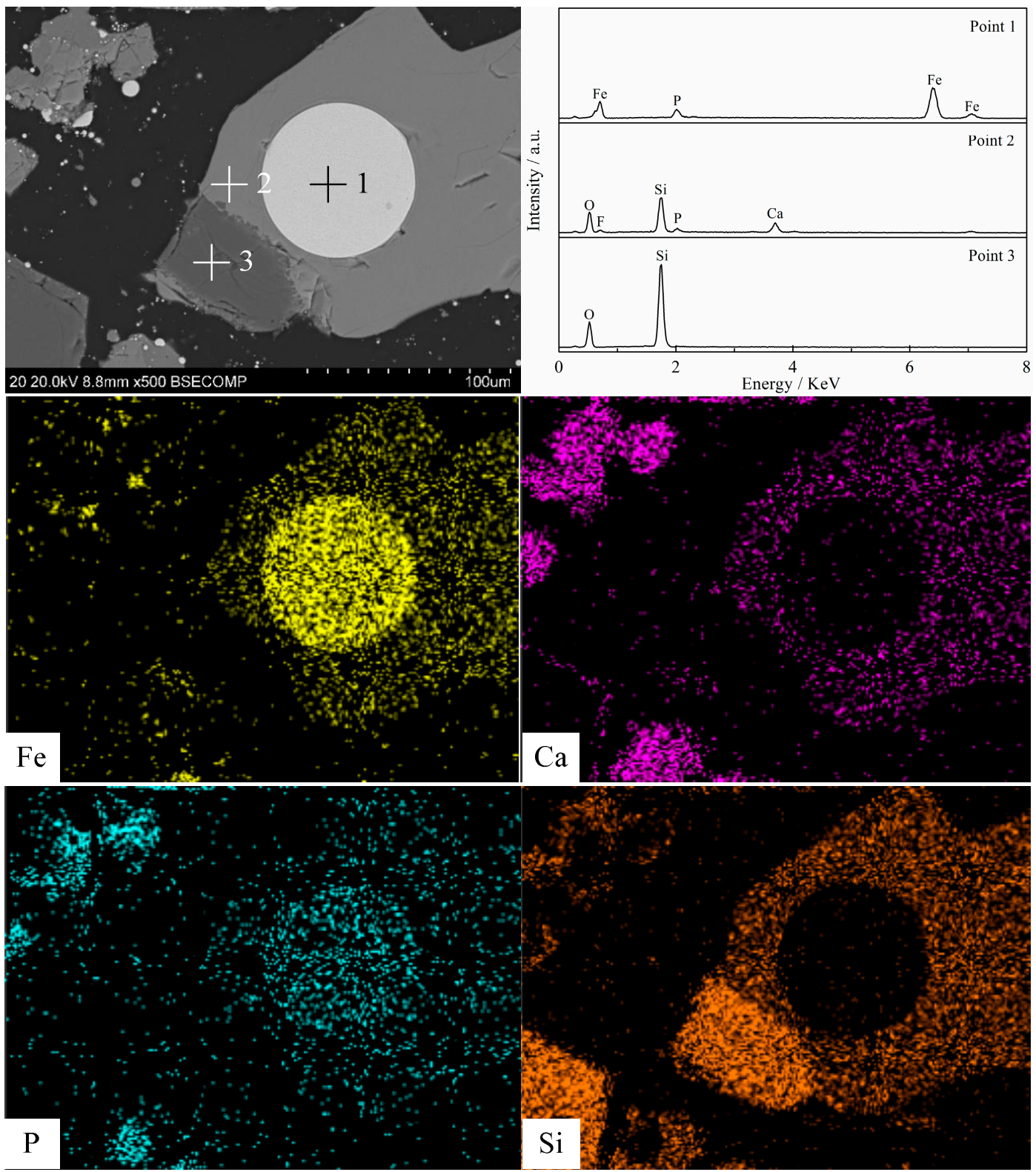

Figure 14. SEM image and EDS spectra and line-by-line scanning analysis of the reduction product in the $\mathrm{Ca}_{10}\left(\mathrm{PO}_{4}\right)_{6} \mathrm{~F}_{2}-\mathrm{SiO}_{2}-\mathrm{Fe}_{2} \mathrm{O}_{3}-\mathrm{C}$ system (a reduction temperature of $1473 \mathrm{~K}$ and reduction time of $60 \mathrm{~min}$ ).

Figure 14 exhibits that the bright white area in point 1 was mainly composed of iron and phosphorus, the gray white area in point 2 was mainly composed of silica, fluorapatite, and calcium silicate, and the gray black area in point 3 was composed of silica.

The reduction products of the $\mathrm{Ca}_{10}\left(\mathrm{PO}_{4}\right)_{6} \mathrm{~F}_{2}-\mathrm{SiO}_{2}-\mathrm{Fe}_{2} \mathrm{O}_{3}-\mathrm{C}$ system were analyzed by elemental scanning electron microscopy (SEM/EDS) under the conditions of a reduction temperature of $1573 \mathrm{~K}$ and reduction time of $10 \mathrm{~min}$. The results are shown in Figure 15. 

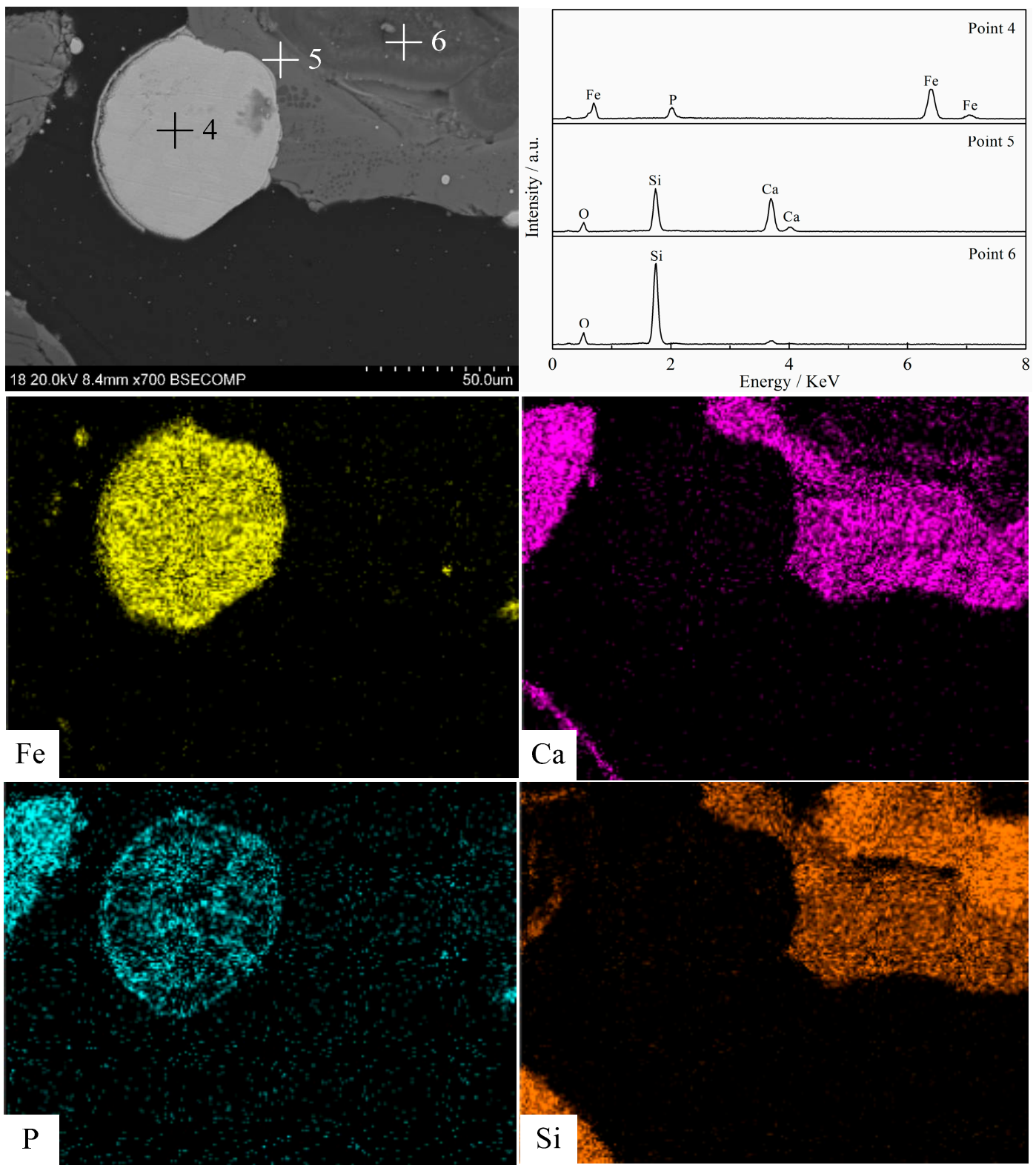

Figure 15. SEM image and EDS spectra and line-by-line scanning analysis of the reduction product in the $\mathrm{Ca}_{10}\left(\mathrm{PO}_{4}\right)_{6} \mathrm{~F}_{2}-\mathrm{SiO}_{2}-\mathrm{Fe}_{2} \mathrm{O}_{3}-\mathrm{C}$ system (a reduction temperature of $1573 \mathrm{~K}$ and reduction time of $10 \mathrm{~min}$ ).

Figure 15 shows the phosphorus content in the gray-white area of point 5 was low, and the area was almost composed of calcium silicate, while the phosphorus content in the iron particles of point 4 was relatively high, which indicated that the fluorapatite in the area of point 5 was almost completely reduced by the action of nearby metal iron and silicon dioxide.

The reduction products of the $\mathrm{Ca}_{10}\left(\mathrm{PO}_{4}\right)_{6} \mathrm{~F}_{2}-\mathrm{SiO}_{2}-\mathrm{Fe}_{2} \mathrm{O}_{3}-\mathrm{C}$ system were analyzed by elemental scanning electron microscopy (SEM/EDS) under the conditions of a reduction temperature of $1573 \mathrm{~K}$ and reduction time of $60 \mathrm{~min}$. The results are shown in Figure 16. 

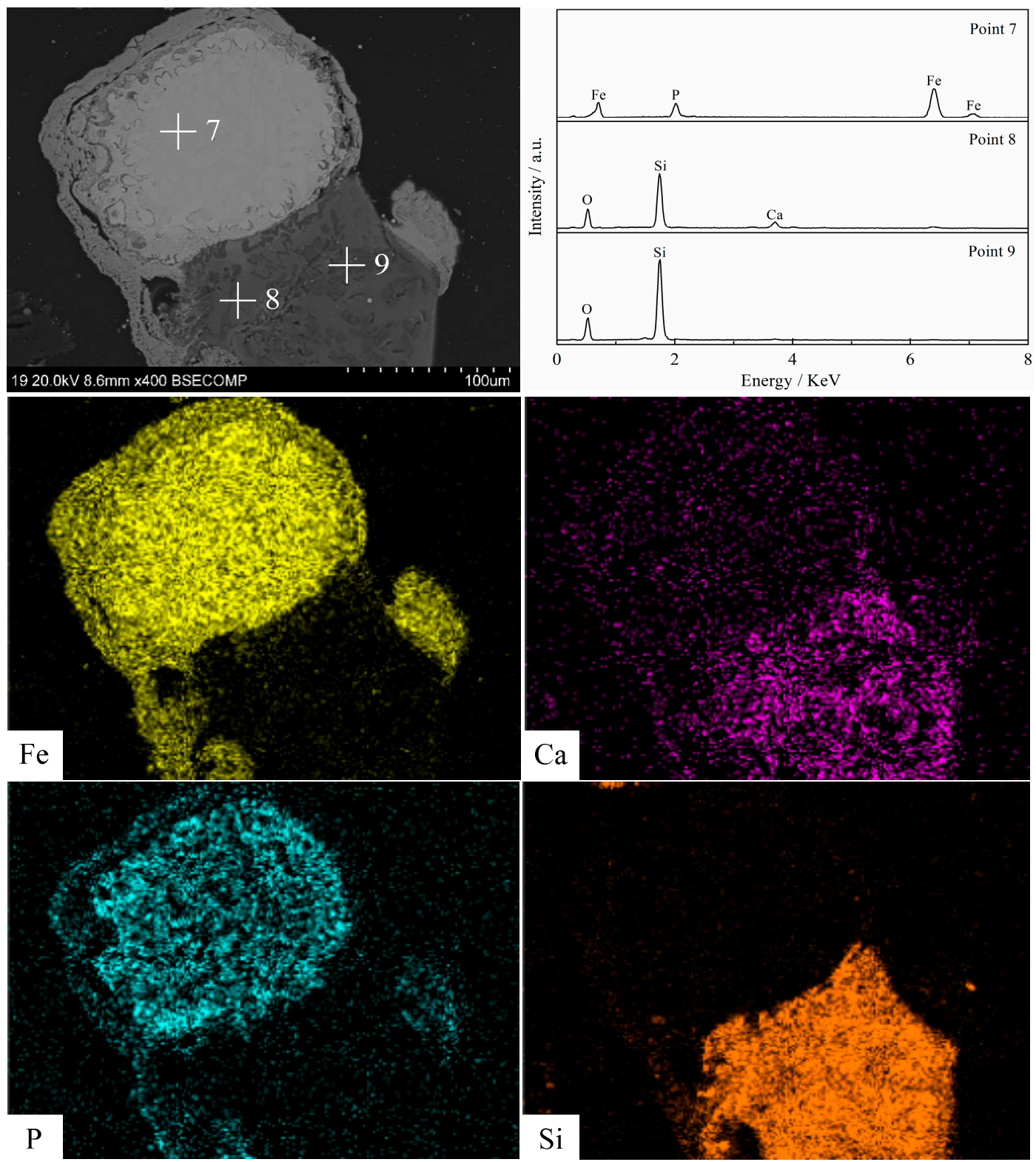

Figure 16. SEM image and EDS spectra and line-by-line scanning analysis of the reduction product in the $\mathrm{Ca}_{10}\left(\mathrm{PO}_{4}\right)_{6} \mathrm{~F}_{2}-\mathrm{SiO}_{2}-\mathrm{Fe}_{2} \mathrm{O}_{3}-\mathrm{C}$ system (reduction temperature of $1573 \mathrm{~K}$ and reduction time of $60 \mathrm{~min}$ ).

Figure 16 shows that there was no fluorapatite aggregate in the region, and the P element was almost completely present in the ferrous phase of the region in point 7. The structure of $\mathrm{SiO}_{2}$ was completely destroyed. The dark gray part of point 9 was residual $\mathrm{SiO}_{2}$, and the light gray part of point 8 was mainly composed of calcium silicate.

From the above analysis, silica (or alumina) promoted the reduction of fluorapatite by forming calcium silicate (or calcium aluminate) at the contact surface with fluorapatite. At a lower reduction temperature or early stage of the reduction reaction, $\mathrm{CaSiO}_{3}$ (or $\mathrm{CaAl}_{12} \mathrm{O}_{19}$ ) was mainly formed by the interaction of calcium fluorophosphate and silica (or alumina), while $\mathrm{Ca}_{3} \mathrm{Si}_{2} \mathrm{O}_{7}\left(\right.$ or $\mathrm{CaAl}_{4} \mathrm{O}_{7}$ ) and calcium fluorophosphate were produced by the interaction with silica (or alumina). The fluorine reaction mainly occurred in the middle and late stages of the reduction reaction and at a higher reduction temperature. With the prolongation of reduction time, the position of reaction between fluorapatite and silica (or alumina) extended from the two-phase contact to the inner phase. The structure of fluorapatite and silica (or alumina) was gradually destroyed, and the reduction degree of fluorapatite was greatly improved. The reduction product of iron oxide could react with fluorapatite to form calcium oxide and 
iron phosphide. The reaction mainly occurred at the interface between iron particles and fluorapatite. Increasing the reduction temperature and prolonging the reduction time were conducive to the growth of iron particles and the reduction of fluorapatite. When the additives were silicon dioxide, alumina, and iron oxide, the effect of metal iron on the reduction of fluorapatite was lower at a lower reduction temperature or shorter reduction time, but with the increase of the reduction temperature and longer reduction time, the effect of metal iron became larger.

\section{Conclusions}

(1) The effect of $\mathrm{SiO}_{2}$ and $\mathrm{Fe}_{2} \mathrm{O}_{3}$ on reducing the initial reduction temperature of fluorapatite was stronger than that of $\mathrm{Al}_{2} \mathrm{O}_{3}$ and $\mathrm{Fe}_{2} \mathrm{O}_{3}$; the initial reduction temperature of fluorapatite was reduced to $985^{\circ} \mathrm{C}$ and $1059{ }^{\circ} \mathrm{C}$, respectively. When the mass ratios of $\mathrm{Al}_{2} \mathrm{O}_{3}, \mathrm{SiO}_{2}$, and $\mathrm{Fe}_{2} \mathrm{O}_{3}$ to fluorapatite were less than $0.6,1.8$, and 1.8 , respectively, the reduction reaction of fluorapatite could be promoted by increasing the dosage of silica, iron oxide, carbon, reduction time, and reduction temperature.

(2) The best kinetic mechanism functions of the $\mathrm{SiO}_{2}-\mathrm{Fe}_{2} \mathrm{O}_{3}-\mathrm{C}$ system and the $\mathrm{Al}_{2} \mathrm{O}_{3}-\mathrm{Fe}_{2} \mathrm{O}_{3}-\mathrm{C}$ system were $\mathrm{A}_{1 / 3}=1 / 3(1-\alpha)[-\ln (1-\alpha)]^{-2}$ and $\mathrm{A}_{1 / 2}=1 / 2(1-\alpha)[-\ln (1-\alpha)]^{-1}$, respectively. Among them, the pre-exponential factor of the kinetics equation of fluorapatite reduction with the $\mathrm{Al}_{2} \mathrm{O}_{3}$ system was $3.26789 \times 10^{9} \mathrm{~min}^{-1}$, the activation energy was $345.479 \mathrm{~kJ} / \mathrm{mol}$, the pre-exponential factor of the kinetics equation with the $\mathrm{SiO}_{2}$ system was $3.89033 \times 10^{7} \mathrm{~min}^{-1}$, and the activation energy was $282.748 \mathrm{~kJ} / \mathrm{mol}$. The activation energy and pre-exponential factor of the reduction kinetics equation in the system containing silica were significantly lower than those in the system containing alumina, which explained that the catalytic effect of silica on the reduction of calcium fluorophosphate was far greater than that of alumina.

(3) Silica (or alumina) promoted the reduction of fluorapatite by forming calcium silicate (or calcium aluminate) at the interface between fluorapatite and silica (or alumina); $\mathrm{CaSiO}_{3}\left(\right.$ or $\mathrm{CaAl}_{12} \mathrm{O}_{19}$ ) was mainly formed in the early stage, while $\mathrm{Ca}_{3} \mathrm{Si}_{2} \mathrm{O}_{7}\left(\right.$ or $\mathrm{CaAl}_{4} \mathrm{O}_{7}$ ) was mainly produced and defluorinated in the later stage. Increasing the reduction temperature and prolonging the reduction time were beneficial to the formation and growth of iron particles and the reduction of fluorapatite.

Author Contributions: Y.S. provided fundings support, designed the experiment and analyzed the characteristics of data mechanism. W.Z. contributed to the operation of the experiment and the writing of the manuscript. Y.H. and Y.L. contributed to the guidance of the experiment and the writing of the manuscript respectively.

Funding: This research was funded by the National Natural Science Foundation of China (Grant No. 51604063), the Liao Ning Revitalization Talents Program (No. XLYC1807111) and the Fundamental Research Funds for the Central Universities of China (No. N180105030).

Acknowledgments: The authors would like to thank the National Natural Science Foundation of China (Grant No.51604063), the Liao Ning Revitalization Talents Program (No. XLYC1807111) and the Fundamental Research Funds for the Central Universities of China (No. N180105030) for financial support.

Conflicts of Interest: The authors declare no conflict of interest.

\section{References}

1. Sun, Y.S.; Zhu, X.R.; Han, Y.X.; Li, Y.J. Green magnetization roasting technology for refractory iron ore using siderite as a reductant. J. Clean. Prod. 2019, 206, 40-50. [CrossRef]

2. Tang, H.Q.; Guo, Z.C.; Zhao, Z.L. Phosphorus removal of high phosphorus iron ore by gas-based reduction and melt separation. J. Iron Steel Res. Int. 2010, 17, 1-6. [CrossRef]

3. Sun, Y.S.; Zhang, Q.; Han, Y.X.; Gao, P.; Li, G.F. Comprehensive utilization of iron and phosphorus from high-phosphorus refractory iron ore. JOM 2018, 70, 144-149. [CrossRef]

4. Cao, Y.Y.; Zhang, Y.R.; Sun, T.C. Dephosphorization behavior of high-phosphorus oolitic hematite-solid waste containing carbon briquettes during the process of direct reduction magnetic separation. Metals 2018, 8, 897. [CrossRef] 
5. Wang, H.H.; Li, G.Q.; Zhao, D. Dephosphorization of high phosphorus oolitic hematite by acid leaching and the leaching kinetics. Hydrometallurgy 2017, 171, 61-68. [CrossRef]

6. Zhang, X.L.; Han, Y.X.; Sun, Y.S.; Li, Y.J. Innovative utilization of refractory iron ore via suspension magnetization roasting: A pilot-scale study. Powder Technol. 2019, 352, 16-24. [CrossRef]

7. Tang, H.Q.; Qin, Y.Q.; Qi, T.F. Application of wood char in processing oolitic high-phosphorus Hematite for phosphorus removal. J. Iron. Steel. Res. Int. 2016, 2, 109-115. [CrossRef]

8. Mamdouh, O.; Timo, F.; Riku, M. Thermally assisted liberation of high phosphorus oolitic iron ore: A comparison between microwave and conventional furnaces. Powder Technol. 2015, 269, 7-14.

9. Zhang, H.Q.; Zhang, Z.Q.; Luo, L.Q.; Yu, H. Behavior of Fe and P during reduction magnetic roasting-separation of phosphorus-rich oolitic hematite. Energy Sources Part A 2019, 1, 47-64. [CrossRef]

10. Kang, Y. Desiliconisation and dephosphorisation behaviours of various oxygen sources in uot metal pre-treatment. Metals 2019, 9, 251. [CrossRef]

11. Ionkov, K.; Gaydardzhiev, S. Amenability for processing of oolitic iron ore concentrate for phosphorus removal. Miner. Eng. 2013, 46-47, 119-127. [CrossRef]

12. Salama, W. Paleoenvironmental significance of aluminum phosphate-sulfate minerals in the upper Cretaceous ooidal ironstones, E-NE Aswan area, southern Egypt. Int. J. Earth Sci. 2014, 103, 1621-1639. [CrossRef]

13. Mamdouh, O.; Timo, F.; Riku, M. Effect of microwave pre-treatment on the magnetic properties of iron ore and its implications on magnetic separation. Sep. Purif. Technol. 2014, 136, 223-232.

14. Mamdouh, O.; Timo, F.; Riku, M. Influence of microwave radiation on the magnetic properties of molybdenite and arsenopyrite. Powder Technol. 2017, 15, 276-281.

15. Xia, W.T.; Ren, Z.D.; Gao, Y.F. Removal of phosphorus from high phosphorus iron ores by selective $\mathrm{HCl}$ leaching method. J. Iron Steel Res. Int. 2011, 18, 1-4. [CrossRef]

16. Wang, J.C.; Shen, S.B.; Kang, J.H.; Li, H.X.; Guo, Z.C. Effect of ore solid concentration on the bioleaching of phosphorus from high-phosphorus iron ores using indigenous sulfur-oxidizing bacteria from municipal wastewater. Process. Biochem. 2010, 45, 1624-1631. [CrossRef]

17. Delvasto, P.; Ballester, A.; Muñoz, J.A.; González, F.; Blázquez, M.L.; Igual, J.M.; Valverde, A.; García-Balboa, C. Mobilization of phosphorus from iron ore by the bacterium Burkholderia caribensis FeGL03. Miner. Eng. 2009, 22, 1-9. [CrossRef]

18. Gao, P.; Li, G.F.; Han, Y.X.; Sun, Y.S. Reaction behavior of phosphorus in coal-based reduction of an oolitic hematite ore and pre-dephosphorization of reduced iron. Metals 2016, 6, 82. [CrossRef]

19. Li, K.Q.; Ni, W.; Zhu, M. Iron extraction from oolitic iron ore by a deep reduction process. J. Iron Steel. Res. Int. 2011, 8, 9-13. [CrossRef]

20. Han, H.; Duan, D.; Yuan, P. Recovery of metallic iron from high phosphorus oolitic hematite by carbothermic reduction and magnetic separation. Ironmak. Steelmak. 2014, 7, 542-547. [CrossRef]

21. Grabke, H.J. Grain boundary segregation of impurities in iron and effects on steel properties. Mater. Eng. ISIJ. 1999, 13, 143-192.

22. Sun, Y.S.; Han, Y.X.; Gao, P.; Wang, Z.H.; Ren, D.Z. Recovery of iron from high phosphorus oolitic iron ore using coal-based reduction followed by magnetic separation. Int. J. Miner. Metall. Mater. 2013, 20, 411-419. [CrossRef]

23. Xu, C.Y.; Sun, T.C.; Kou, J.; Li, Y.L.; Mo, X.L.; Tang, L.G. Mechanism of phosphorus removal in beneficiation of high phosphorous oolitic hematite by direct reduction roasting with dephosphorization agent. Trans. Nonferrous Met. Soc. China. 2012, 22, 2806-2812. [CrossRef]

24. Yu, W.; Sun, T.C.; Kou, J.; Wei, Y.X.; Xu, C.Y.; Liu, Z.Z. The function of $\mathrm{Ca}(\mathrm{OH})_{2}$ and $\mathrm{Na}_{2} \mathrm{CO}_{3}$ as additive on the reduction of high-phosphorus oolitic hematite-coal mixed pellets. ISIJ Int. 2013, 53, 427-433. [CrossRef]

(C) 2019 by the authors. Licensee MDPI, Basel, Switzerland. This article is an open access article distributed under the terms and conditions of the Creative Commons Attribution (CC BY) license (http://creativecommons.org/licenses/by/4.0/). 